DIW BERLIN

Discussion Papers

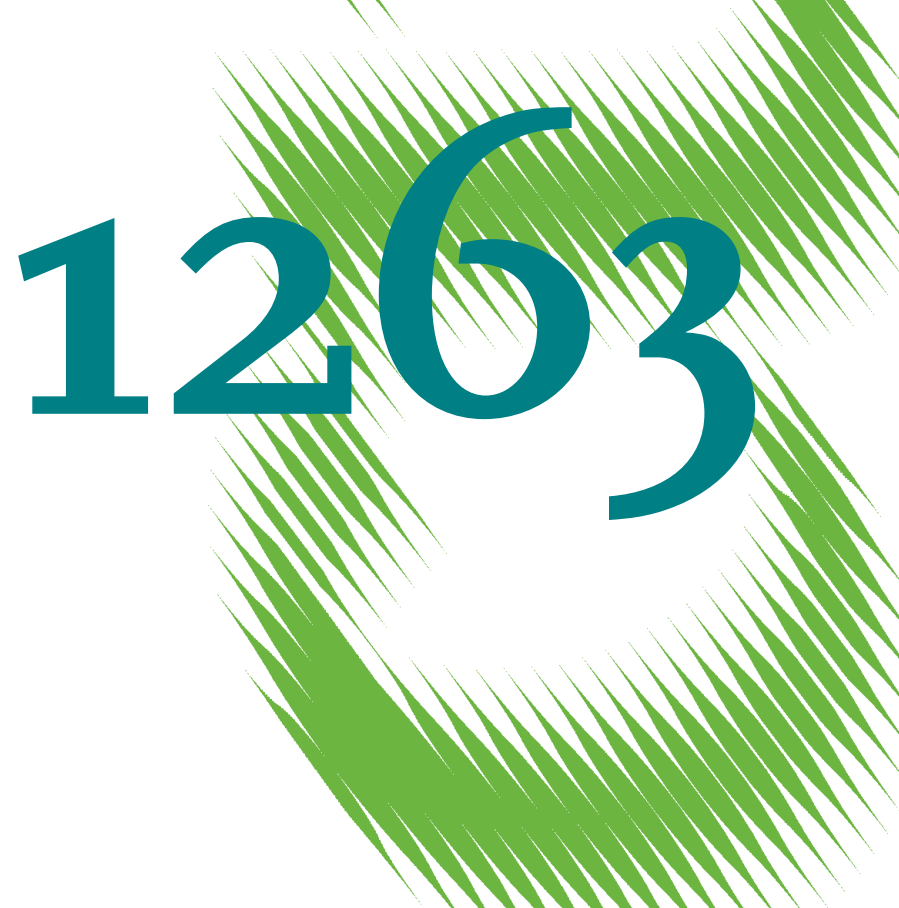

Chinese Renewable Energy Technology Exports:

The Role of Policy, Innovation and Markets 
Opinions expressed in this paper are those of the author(s) and do not necessarily reflect views of the institute.

IMPRESSUM

(C) DIW Berlin, 2013

DIW Berlin

German Institute for Economic Research

Mohrenstr. 58

10117 Berlin

Tel. $+49(30) 89789-0$

Fax +49 (30) $89789-200$

http://www.diw.de

ISSN print edition $1433-0210$

ISSN electronic edition 1619-4535

Papers can be downloaded free of charge from the DIW Berlin website:

http://www.diw.de/discussionpapers

Discussion Papers of DIW Berlin are indexed in RePEc and SSRN:

http://ideas.repec.org/s/diw/diwwpp.html

http://www.ssrn.com/link/DIW-Berlin-German-Inst-Econ-Res.html 


\title{
Chinese Renewable Energy Technology Exports: The Role of Policy, Innovation and Markets
}

\author{
Jing $\mathrm{Cao}^{\mathrm{a}}$, Felix Groba ${ }^{\mathrm{b}_{*}}$ \\ ${ }^{a}$ School of Economics and Management, Tsinghua University, Beijing, China \\ Tel: +861062792726 ,E-mail: caojing@sem.tsinghua.edu.cn \\ ${ }^{b}$ German Institute for Economic Research, Mohrenstrasse 58, 10117 Berlin, Germany \\ Tel: +4930 89789681, Fax: +4930 89789681, E-mail:F.Groba@diw.de \\ * Corresponding Author
}

\begin{abstract}
Chinese companies have become major technology producers, with the largest share of their output exported. This paper examines the development of solar PV and wind energy technology component (WETC) exports from China and the competitive position of the country's renewable energy industry. We also describe the government's renewable energy policy and its success in renewable electricity generation as well as increasing renewable energy innovation and foreign knowledge accumulation, which may drive export performance. We aim at empirically identifying determinants of Chinese solar PV and WETC exports. We estimate an augmented gravity trade model using maximum likelihood estimation. Besides controlling for standard variables derived from the gravity literature, we consider additional explanatory factors by accounting for market, policy and innovation effects steaming from both importing countries and China. We use a panel dataset representing annual bilateral trade flows of 43 countries from the developed and developing world that imported solar PV and WETCs from China between 1996 and 2008.

The analysis shows that while the national market remained small for solar PV, the industry successfully entered foreign markets. The export performance of firms producing WETC increased but remained relatively small while the country developed a large home market. Empirical results indicate that high income countries, with a large renewable energy market and demand side policy support scheme, in terms of incentive tariffs, are increasingly importing solar PV components from China. We show that trade costs have a negative impact on exports of solar PV components but not WETC. Additionally, we find a positive impact of research and development (R\&D) appropriation growth, especially from provincial governments in China, but no evidence that bilateral knowledge transfer and indigenous innovation affect exports.
\end{abstract}

Keywords: China, Gravity model, Trade, Innovation, Policy, Renewable Energy Technologies

JEL Classification: C32, F14, O30, Q42, Q48, Q56 



\section{Introduction}

Since 1990, China's economic growth and export performance has been exceptional. The rapid growth in energy consumption and carbon emissions makes China a decisive player in global climate negotiations. In attempting to create more sustainable growth, China has introduced various policies designed to increase its renewable energy generation capacity and to establish an industrial base for clean technology production. With respect to the latter, China is particularly successful as its clean technology industry experienced a remarkable development. The solar photovoltaic (PV) module producing industry, including companies like Suntech, JA Solar and Yingli, is extremely prosperous with double digit growth rates since 2000 ( 3 MW in 2000, China's solar PV panel industry became the largest global producer, making 10,852 MW in 2010, which accounted for 45 percent of world production in 2010 (Algieri et al., 2011, EPI, 2011). China's wind turbine production also experienced a similar rapid growth. Companies such as Sinovel, Goldwind, Dangfang and Ming Yang increased their production from USD 26 million in 2003 to USD 104 million in 2005, building a supply capacity of 17 gigawatt; some 41 percent of the global market (Caprotti, 2009, BTMConsult, 2011). At the same time, the Chinese government increased its efforts to close a knowledge gap to developed countries by increasing its research and development (R\&D) spending on renewable energies and energy efficiency as well as by introducing numerous policies to support indigenous innovation and attract foreign knowledge. Yet, as this paper will highlight that the local market for renewable energy technologies components in China remained small until recently, with electricity generation from renewable sources contributing only a marginal share to total electricity generation. Consequently, the largest share of solar PV and wind energy equipment production is exported - to only a few high-income countries - and China became the largest exporter of solar PV modules and a major exporter of wind energy technology components (WETC).

Literature describing and examining the dynamics of trade in clean energy technology remains sparse and, with the exception of Algieri et. al (2011), does not account for development in China. Consequently we contribute to the existing literature in two ways. First, our research examines the development of solar PV and wind energy technology component (WETC) exports from China and the competitive position of the 
country`s renewable energy industry. Furthermore, we describe the government's renewable energy policy and its success in terms of renewable electricity generation and increasing renewable energy innovation and foreign knowledge accumulation in China. Second, as in the first study, we empirically identify driving factors of Chinese solar PV and WETC exports. We conduct an ex-post econometric study using an augmented gravity model. We use a panel dataset representing annual bilateral trade flows of 43 countries from the developed and developing world that imported solar PV and WETCs from China between 1996 and 2008. Overall our data represents about 90 percent of Chinese exports with respect to both technologies. Besides controlling for standard socioeconomic variables derived from the gravity trade literature, we consider several explanatory factors accounting for market, policy and innovation effects steaming from both importing countries and China. Specifically, we are interested in the effect of renewable energy support schemes and the renewable energy market size in importing countries on export flows from China. Furthermore, the role of Chinese R\&D policy, innovation and bilateral technology transfer and the Chinese demand market for solar PV and WETCs is of interest.

We show that China experienced a rapid export growth for both solar PV and wind energy equipment, but that it only runs large export surplus with a few OECD countries. Main results support the descriptive analysis, as income both in importing countries and China are important export determinants. Furthermore, at least for solar PV, the results indicate a strong role for market size and policy setup in importing countries as well as trade costs in terms of tariffs applied to imports from China. The effect of the market size in China for solar PV components and WETCs is in line with the descriptive observation. While the national market remained small for solar PV, the solar PV component industry became particularly successful in targeting foreign markets. On the contrary, while the country developed a large home market for WETC, its export performance in the sector increased but remained relatively small. Additionally, we find a positive impact of R\&D appropriation growth, especially from provincial governments in China, but no evidence that bilateral knowledge transfer and indigenous innovation has an effect on Chinese exports of solar PV components and WETC. Hence, our analysis calls for more research on the topic as our innovation measures presumably does not cover other means of 
innovation, such as purchasing manufacturing equipment or hiring a skilled foreign trained workforce, and respective supportive policies such as educational investments.

Nevertheless, the results of our study are of interest to policy makers. Among other things, the results suggest that a renewable energy supportive market structure is essential to obtain solar PV technology in an international market. Furthermore, on the one hand, the reduction import tariffs can significantly increase the availability of affordable solar PV technologies from China. Yet, on the other, increasing tariffs along WTO law can also serve as a tool for reducing solar PV component imports from China. Further, the results give a hint that future growth in the Chinese home market for solar PV might eventually decrease the current large export surplus of the sector, as the home market is supplied instead.

The analysis is organized as follows. Section 2 provides a literature overview. Section 3 highlights the development of Chinese exports of renewable energy technology components focusing on solar PV and wind energy technology components (WETC) and in order to outline supply side mechanisms - brings it in line with efforts undertaken by the central and provincial governments to promote renewable energies in China. Section 4 presents the empirical framework. Section 5 describes data used to estimate determinants of imports of these technologies from China. The results are presented in Section 6 and discussed in Section 7.

\section{Related Literature}

Literature on innovation, learning and the determinants of export development generally stems from two theoretical traditions. Literature rooted in the Heckscher-OhlinSamuelson model and its neo-endowment approach determines trade by the relative factor availability of labor, capital and knowledge. The other theoretical approach, influenced by the Ricardian school, understands technology differences between trading partners as the main determinant of trade between developed countries ( Vernon, 1966). Innovation and technology is identified as an important non-price factor positively affecting bilateral trade between countries (Magnier and Toujas-Bernate, 1994 Verspagen and Wakelin, 1997, Krugman, 1979, Grossman and Helpman, 1991, Eaton and 
Kortum, 2002). The empirical literature outlining the importance of innovation, government policies that encourage domestic R\&D, investment and technology diffusion, as well as the levels and similarities of markets is large, but mostly focuses on developed countries. Greenhalgh, 1990, Chengang Wang et al., 2010, Levinson, 2009, Papaconstantinou, 1997, Madden et al., 1999, Wakelin, 1998b). With the increasing competitiveness of developing countries' exports, some empirical studies analyze these issues focusing on emerging markets, in particular East Asian economies ( $\underline{\text { Pamukcu, 2003, }}$ Hasan and Raturi, 2001, Madden et al., 1999). Edmonds et. al (2008) show that China's excessive foreign trade orientation substantially varies between countries due to growth of foreign invested firms and their respective links to home markets. Arguing that government policies play a role in nurturing domestic production capabilities, Rodrik (2006) and Schott (2008) suggest that China has developed comparative advantages in highly sophisticated good exports that are not comparable with its development level. Other studies also support the view that foreign direct investment (FDI) and innovation are important drivers for entering export markets. For instance, Zhang and Song (2000) find evidence that increased levels of FDI positivly affect manufacturing export performance, not only through exports generated by foreign affiliates but also by host country industries. In line with the theoretical literature on the importance on innovation and learning for exporting (Bell and Pavitt, 1993, Westphal, 2002), numerous empirical studies find evidence that innovation activities, technology spilloves through imports, and linkages to multinational companies have a positive effect on Chinese export performance (Guan and Ma, 2003, Guan et al., 2009, Motohashi and Yuan, 2010, Park and Lippoldt, $\underline{2008})$. Fu and Gong (2011), for instance, using a panel of Chinese firm-level data, analyze the role of indigenous and foreign innovation efforts in technological upgrading finding that indigenous firms are leading in low- and medium technology industries, while foreign firms lead in the high technology sector. Wignaraja (2012) identifies that technology transfer from multinationals in combination with systematic investments in and upgrading of minor technological activities as important drivers behind the export success of the automobiles and electronics industry. In the context of the effect of innovation on trade there are two often used measures of innovation that are also used in this study - R\&D spending and patents. Empirical evidence finds that increasing R\&D 
spending might explain the export success of most countries (Hirsch and Bijaoui, 1985 Buxton et al., 1991, Keesing, 1967) and China (Zhao and Li, 1997). Yet, R\&D spending, reflecting only one input into the innovative process, might be an insufficient measure. Consequently, patent data, reflecting innovative output, is used as a proxy for innovation and technology transfer. Several studies using patent data further support the view that innovation is a decisive element in determining trade flows (Zeng, 2009, Soete, 1987,

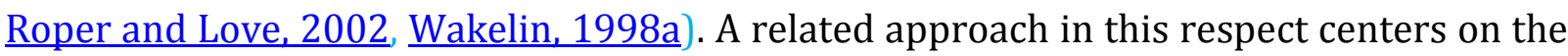
effect of intellectual property rights (IPR) on trade flows. Most empirical studies focus on exports from industrialized nations to a group of developed and developing importer countries. (Maskus and Penubarti, 1995, Rafiquzzaman, 2002, Smith, 1999, 2001). In the early 2000s, studies began to focus on developing countries' trade flows and the role of

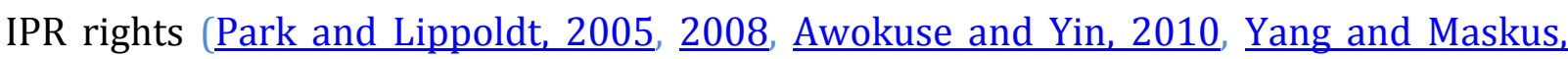
2009, Branstetter et al., 2005). With respect to China, Awokuse and Yin (2010) present some empirical evidence suggesting that strengthened IPR protection in China significantly affected imports of knowledge intensive products.

Some studies analyze the role of innovation and government policies in explaining the rapid development of the renewable energy sector in China. De la Tour et al. (2011) describe the role of innovation and technology transfer of the solar PV industry in China. In a descriptive market study they find that Chinese producers attained their current world position by purchasing manufacturing equipment and by recruiting executives from amongst a skilled Chinese diaspora but that their innovation performance is driven by national policies designed to close the innovative gap in critical areas. Similarly, $\mathrm{Wu}$ and Mathews (2012), ignoring trade, investigate knowledge flows from advanced countries finding that the main foreign knowledge sources for China in the sector are the US, Japan and Germany. They also outline a rising dependence of China on its own knowledge generation, in particular from the public research institutes and universities. With respect to the Chinese wind turbine manufacturing industry Lewis $(\underline{2005}, \underline{2011})$ and $\mathrm{Ru}$ et. al (2012) show that public policy plays a key role in the transition of from imitation and cooperation to indigenous innovation. Yet, studies analyzing trade dynamics in clean technology industries are limited, especially with respect to developing countries. Focusing on export flows from developed countries, Constantini and Crespi (2008) and 
Constantinin and Mazzanti (2012) find that stringent environmental regulation and strong national innovation systems have a significant positive effect on exports of energy technologies. Algieri et al. ( $\underline{2011}$ ) analyze trade dynamics of the global PV industry and describe the competitiveness of major exporting countries. Focusing on US PV exports, they find a relationship between PV exports, foreign income and relative prices, but ignore the role of innovation. Analyzing renewable power equipment exports to the US, Sawhney and Kahn (2012) find that larger countries export significantly more and that the exporting countries' domestic renewable power generation has a positive significant impact as well. Furthermore, sector specific foreign direct investment from the US to poor exporting countries determines export growth.

In summary, while there is some evidence regarding developed countries' exports in clean energy technologies and the role of innovation and environmental policy for the creation of a clean tech industry, there is little with respect to China. In the present paper we focus on solar PV and wind energy technology component (WETC) exports from China. We link studies on policy effects and innovation in this sector to studies analyzing trade determinants of a new industry. We identify the relationship between Chinese export performance, policy efforts and innovation activities on the supply side within China, as well as drivers on the demand side in importing markets.

\section{Chinese exports of solar PV and wind energy components and renewable energy policy in China}

International trade is a predominant element of the Chinese economic development. Even though growth rates have slowed since 2007 China has seen several annual growth rates of 10 percent since the 1990s. Trade flows grew even faster after the country was formally admitted to the World Trade Organization (WTO) in 2001 (Edmonds et al., 2008). The composition of Chinese trade changed as the country moved from a comparative advantage in trade with low technology based processed foods, textiles and manufactured materials in the 1980s and 1990s, to an increasing more technology embodied trade in machinery and equipment (Yue and Hua, 2002). Using a data set covering bilateral trade relations we find that a similar high-tech components trade 
pattern is reflected in the country's exports and imports of renewable energy technology equipment. In this section we describe the export dynamics and the competitive position of the Chinese renewable energy branch. Data was obtained from UN Comtrade (2011) based on relevant Harmonized Commodity and Coding System (HS) codes (Appendix 1). ${ }^{1}$ The approach allows for a detailed analysis of technology specific trade flows between countries, but does not permit an assessment with respect to the quality of traded goods ( the policy regime supporting renewable energy investment, generation development and innovation in China, in order to identify potential effects of both technology demand and supply side policies on trade in the subsequent empirical analysis.

\subsection{Development and diversity of Chinese clean technology trade}

Global trade of renewable energy technologies grew only marginally before 2000, but has increased sharply since then (Costantini and Crespi, 2008, Groba, 2011). Figure 1 highlights that Chinese exports of solar PV components lagged behind this development, but increased sharply after 2006. Since then, Chinese solar PV exports have increased by a factor of 26, reaching approximately USD 32 billion in 2010. The share of Chinese exports across all global exports increased from 5 percent in 1996 to 39 percent in 2010, making China the leading exporter of this technology (Appendix 2). At the same time, imports to China increased by a factor of 12; increasing the Chinese share of global imports from 3 to 9 percent. While China has become an importer of components as well, its global import share remained low and China developed a large export surplus in this sector. A similar, but weaker, development can be observed in WETC trade, where Chinese exports increased by a factor of 12, raising the market share from 2 percent in 2000 to 6 percent in 2010 (Figure 2). In terms of China's trade composition, the share of solar PV equipment exports out of total Chinese exports more than tripled from below 1 percent in 2000 to about 3 percent in 2010. Yet, for wind technology component exports, the share remains significantly lower.

\footnotetext{
${ }^{1}$ World Integrated Trade Solution: http://wits.worldbank.org/wits/ Typologies of components relevant to exploit renewable energies are well defined, see: OECD and Eurostat (1999); Steenblik

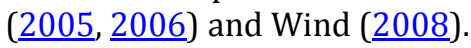


Figure 1: Development of Chinese exports and imports of solar PV energy technology components.

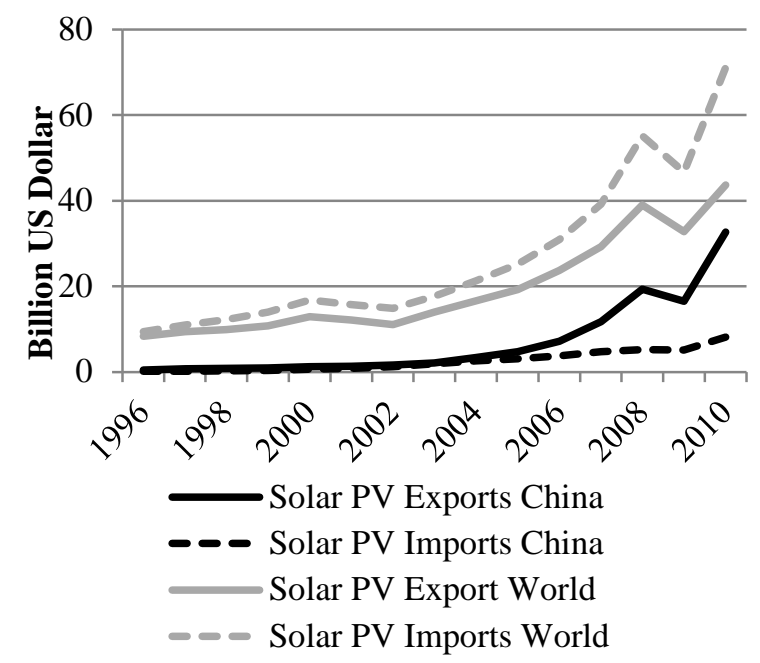

Notes: World indicates rest of world without China Source: authors' calculations based on UNCTAD Comtrade 2011
Figure 2: Development of Chinese exports and imports of wind energy technology components.

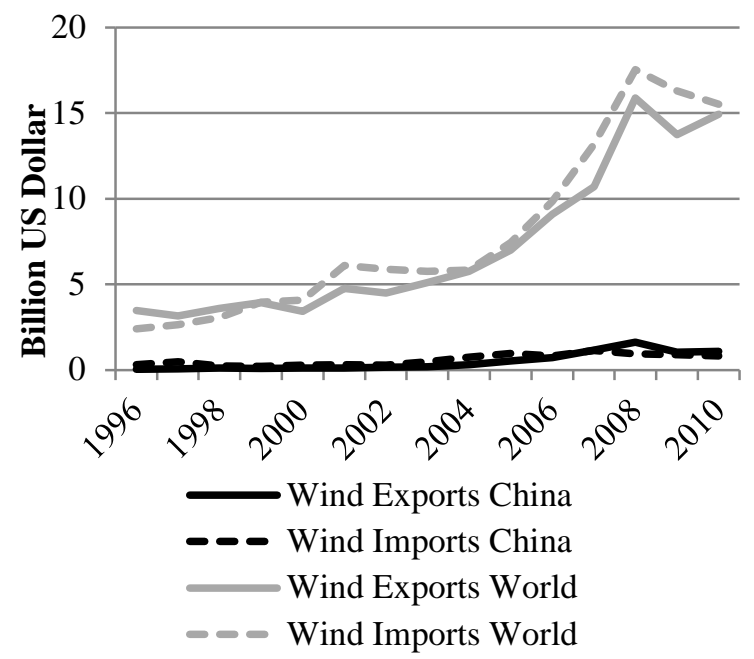

Notes: World indicates rest of world without China Source: authors' calculations based on UNCTAD Comtrade 2011

Analyzing sectoral indices of trade related competitiveness, such as relative world market shares (RWS) and relative trade positions (RTP), confirms an increasing export specialization in both technology segments and traces Chinese competitiveness in the international market (Appendix 3). The share of these products in Chinese total exports is generally higher than the global average and has increased sharply since 2000 . The RTP indicates that Chinese exporters are better able to penetrate foreign markets than foreign exporters are to penetrate the Chinese market highlighted by an increasing gap between the exports and imports. Overall, the export-import relationship of solar PV and WETC relative to the total export import ratio indicates a clear and increasing relative comparative advantage (RCA) of the sector (Appendix 3). This is in line with earlier finding in the literature showing that China moved to an increasing comparative advantage in machinery and equipment (Yue and Hua, 2002).

Yet, the successful export story in the solar and wind sector is unequally distributed across the importing countries and thus in line with earlier findings of China's excessive 
orientation toward foreign trading with high income countries (Rodrik, 2006 $\underline{\text { Schott, }}$ $\underline{2008}$ Edmonds et al., 2008). The major markets importing Chinese solar PV components are OECD countries, which account for 80 percent of respective exports. Countries such as Germany, the US and Italy experienced a two digit, increasing import share of these technologies from China. Other regions contribute little to the Chinese export share, as only marginal volumes are exported to other emerging and developing countries (Figure 3 , Appendix 4). Trade with wind energy technology components shows similar pattern of trade relations although OECD countries account for only 50 percent of Chinese exports and there is considerably more regional trade within the East Asian and Pacific region.

Figure 3: Export flow of solar PV technology components 2008 by region in billion US Dollar.

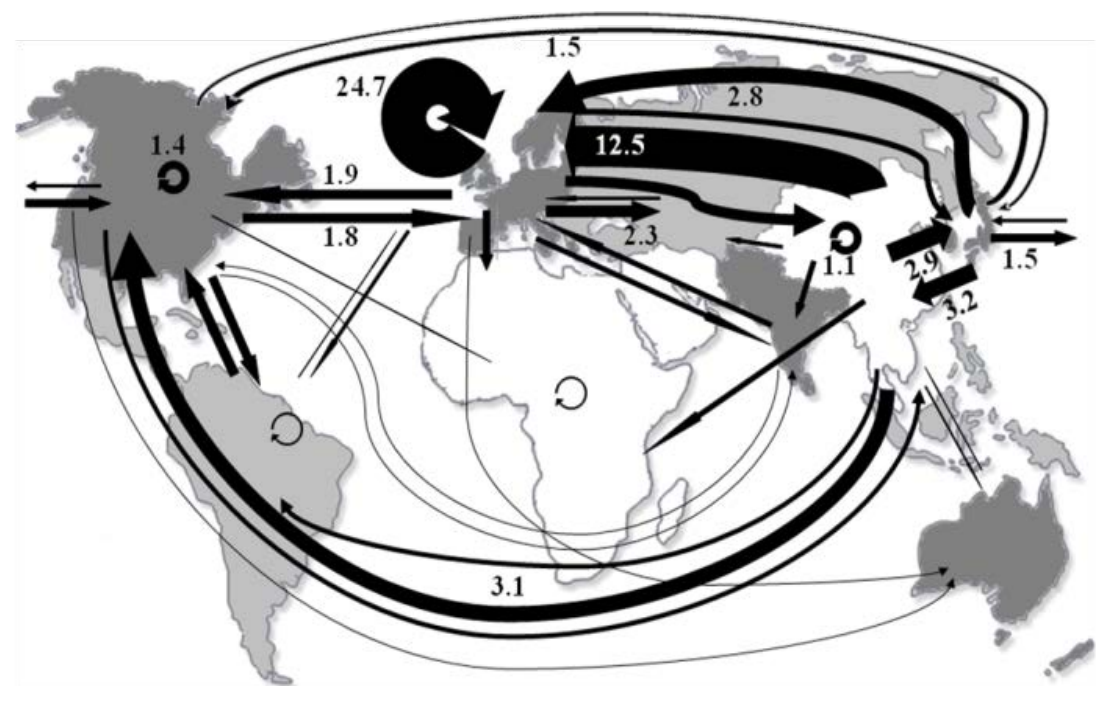

Source: Authors' calculations and illustration based on UN Comtrade 2011 from World Integrated Trade Solution website: http://wits.worldbank.org/wits/.

\subsection{Renewable energy policy and RE electricity generation in China}

Renewable energy policies in OECD countries and China are comparable to some extent as they can be described as a mix of demand and supply driving mechanisms to foster generation and innovation. However, there are also substantial differences. OECD countries largely support renewable energy development through demand generating policies such as feed-in tariffs (FIT), renewable energy portfolios (RPS), and tax 
measures. Public spending on renewable energy R\&D, on the other hand, has not increased since the 1990's, save for bioenergy (IEA, 2004). China's national and provincial governments have implemented numerous policies fostering both electricity generation from renewable sources and innovation of respective technologies (Table 1). However, in terms of policy success, differences between increasing investment or electricity generation on the one hand innovation and industrial development on the other are evident.

Table 1: Selection of national and provincial government policies and programs targeting solar $\mathrm{PV}$ and wind renewable energy dissemination and innovation in China

\begin{tabular}{|c|c|c|}
\hline Year & Policy & Policy Type and Aim \\
\hline 1986 & $\begin{array}{l}\text { State High-Tech Development Plan } \\
\text { (863 Program) }\end{array}$ & R\&D for Technology Development \\
\hline 1993 & Science and Technology Law & Policy Process to support technology development \\
\hline 1996 & Brightness Program & $\begin{array}{l}\text { Policy Process to increase renewable energy } \\
\text { electricity generation }\end{array}$ \\
\hline 1997 & $\begin{array}{l}\text { National Basic Research Program } \\
\text { (973 Program) }\end{array}$ & R\&D Technology Development \\
\hline 1998 & Energy Conservation Law & $\begin{array}{l}\text { Policy Process to increase renewable energy } \\
\text { electricity generation }\end{array}$ \\
\hline $2001 / 2003$ & Reduced Value Added Tax for RE & $\begin{array}{l}\text { Financial Support to increase renewable energy } \\
\text { electricity generation }\end{array}$ \\
\hline $\begin{array}{l}\text { 2003(ende } \\
\text { d) }\end{array}$ & Wind Power Concession Program & $\begin{array}{l}\text { Incentive/Subsidies to increase renewable energy } \\
\text { electricity generation }\end{array}$ \\
\hline $\begin{array}{l}2006 \\
/ 2009\end{array}$ & Renewable Energy Law & $\begin{array}{l}\text { Policy Process to increase renewable energy } \\
\text { electricity generation }\end{array}$ \\
\hline 2006 & National Climate Change Program & Policy Process \\
\hline 2007 & $\begin{array}{l}\text { Hainan Province Plan for the } \\
\text { Construction of Wind Farms }\end{array}$ & $\begin{array}{l}\text { Public Investment to increase renewable energy } \\
\text { electricity generation }\end{array}$ \\
\hline 2007 & Shandong Province Energy Fund & $\begin{array}{l}\text { Public Investment/ R\&D for Technology } \\
\text { Development and industrial process }\end{array}$ \\
\hline 2008 & $\begin{array}{lll}\text { Shandong } & \text { Province } & \text { Village } \\
\text { Renewable Energy Regulation } & \\
\end{array}$ & $\begin{array}{l}\text { Incentive/Subsidies, Regulatory Instruments to } \\
\text { increase renewable energy electricity generation }\end{array}$ \\
\hline 2008 & $\begin{array}{l}\text { Shandong Province One Million } \\
\text { Rooftops Sunshine Plan }\end{array}$ & Policy Process, Regulatory Investments \\
\hline
\end{tabular}

Chinese demand side policy to foster investment in renewable energy generation is lagging behind policy implementation in OECD countries and faces several obstacles. The Renewable Energy Law was only introduced in 2006 and respective feed-in tariff 
policies were enacted in 2009.(Cherni and Kentish, 2007, Peidong et al., 2009, REN21, $\underline{2009}$, Feng Wang et al., 2010, Xinyu et al., 2011, $\mathrm{Hu}$ et al., 2010, Ma et al., 2010). Subsequently, net electricity generation from solar PV sources increased from ten million KWh in 1996 to 150 million KWh in 2008, supplying only a small share of the total electricity generation (EIA 2012). In contrast to Germany, which in 2008 generated 4.4 billion kWh of electricity from solar sources, the local market in China has remained small small until 2008 (Figure 4). A different picture appears with respect to wind energy. While only 100 million kWh of electricity was generated from wind energy in 1996, a remarkable increase occurred especially after 2005 (Figure 5).

Figure 4: China solar PV electricity capacity and generation development $1996-2010$.

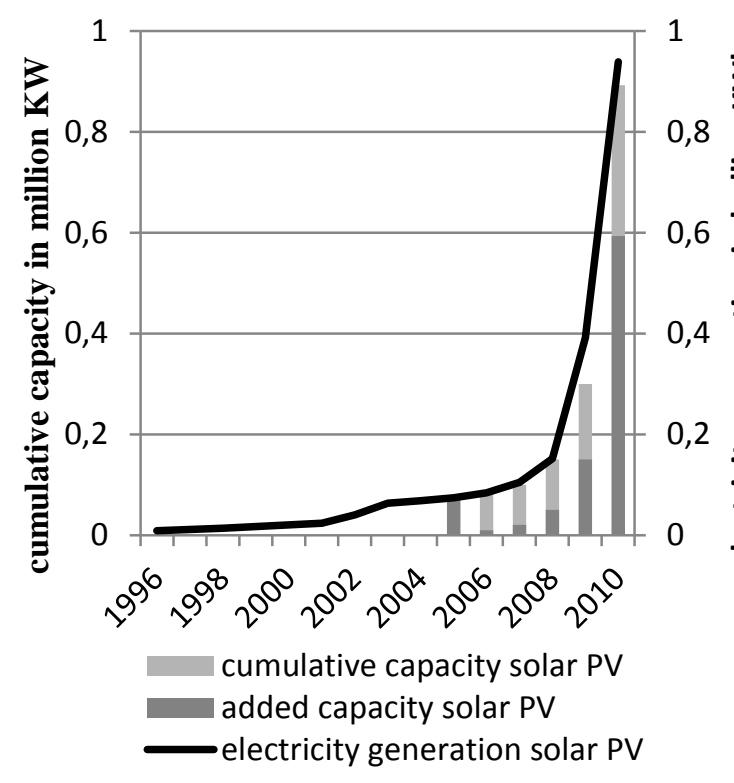

Figure 5: China wind energy electricity capacity and generation development $1996-2010$.

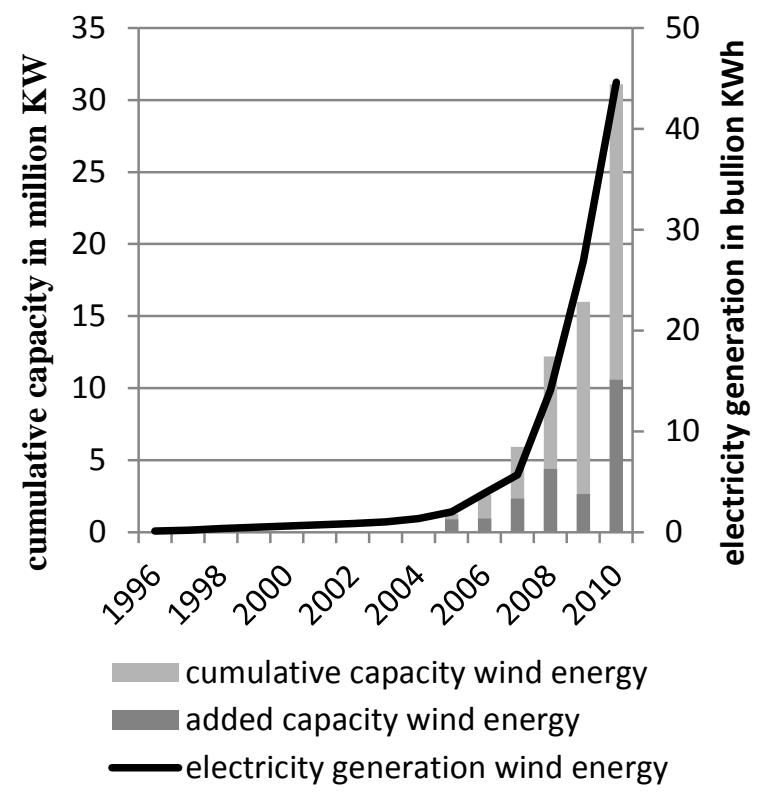

Notes: Data on capacity development in China is available only for a shorter time period but underlines the highlighted development. Solar PV capacity increased from 0.07 million KW in 2005 to 0.89 million KW in 2010. Wind energy capacity increased from 1.26 million KW in 2005 to 31.1 million KW in 2010. Sources: EIA (2011), China Renewable Energy Society (2010)

According to 2012 EIA`s international energy statistics, 14 billion KWh of electricity was generated from wind energy sources in 2008. This soared to 73 billion KWh in 2011, making China one of the world's largest electricity producers from wind 
energy. Overall these figures emphasize that that national market for wind energy components in China developed faster until 2008 and is still significantly larger than the market for solar PV components. ${ }^{2}$

\subsection{R\&D, innovation and technology transfer in China}

With respect to the supply side policies, China, in contrast to OECD countries, substantially increased its public R\&D spending in order to improve its technological knowledge base. For instance, China's gross R\&D appropriations increased from 30.2 billion Yuan (USD 3.6 billion) in 1996 to 355 billion Yuan (USD 51.8 billion) in 2008 (World Bank, 2011, MOST, 2011). With respect to clean energy technologies, the National High-Tech R\&D Program (863 Program) established in 1986 and the National Basic R\&D Program (973 Program) from 1997, have provided most of the direct funding on

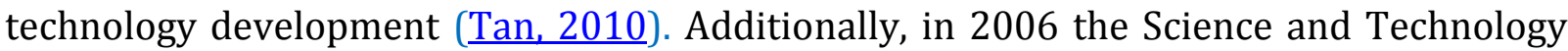
National Plan was established giving a top priority to clean energy technologies and environmental protection. It has introduced several measures to stimulate private sector R\&D and innovation in China (Tan, 2010). Programs supporting science and technology (S\&T) development have become increasingly important at both the national and regional levels, with provincial government R\&D spending recently catching up, reaching a similar magnitude as central government fund provisions. The central government R\&D appropriation directed to renewable energy increased from 21.1 billion Yuan (USD 2.5 billion) in 1996 to 104.8 billion Yuan (USD 15.2 billion) in 2008. While local or regional governments spend 7.8 billion Yuan (USD 940 million) in 1996 this amount increased to 105.7 billion Yuan (USD 15.4 billion) in 2008 (Figure 6).

Figure 6: Central and provincial government R\&D appropriation directed to renewable energy 1996 - 2008

\footnotetext{
${ }^{2}$ Admittedly, the picture changed after 2008 with stongly increasing solar PV capacity and generation development. In 2011 China allready produced 3 billion KWh of solar electricity.
} 


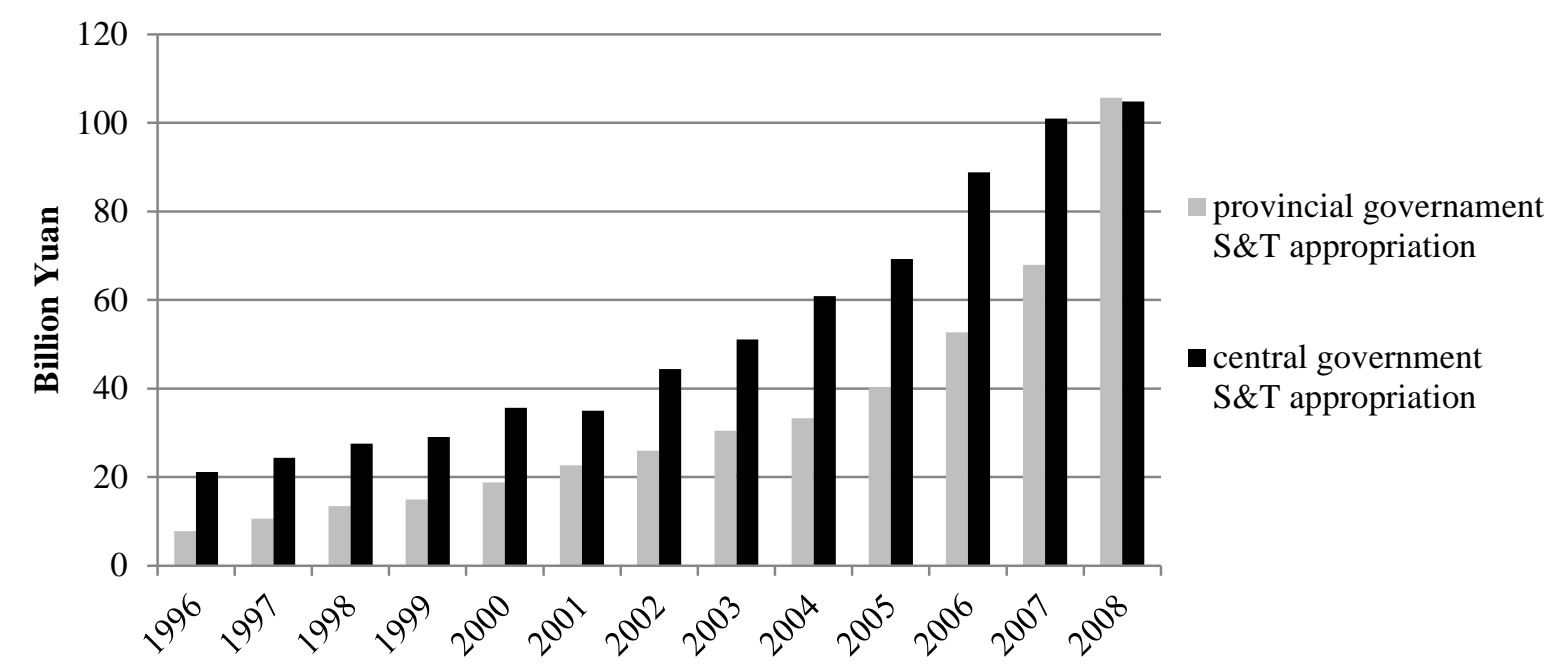

Sources: Tan(2010) and Ministry of Science and Technology (MOST) - China Science \& Technology Statistics Data Book

Government R\&D spending is only one measure of innovative activity and might be insufficient, as it only reflects inputs into the innovative process without measuring the research output. In this research, longer time series data recording China's R\&D spending specifically on solar PV and wind energy is not available. Additionally, using government $R \& D$ spending neglects $R \& D$ efforts by industry as well as the potential role of foreign knowledge. Griliches (1990) and Popp et. al. (․111) highlight that patent data provides meaningful alternative indicators on innovation and technology transfer as they focus on inventive process output and provide information on the origin of the invention, the technology and the applicant. In China, IPR rights were strengthened by major amendments to the Chinese patent law in 1995 and 2001 to set appropriate incentives for

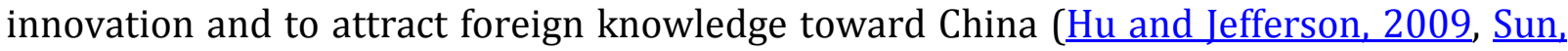
2003). Some studies analyze the development of innovation, technology transfer and patenting showing that the increased propensity to patent by foreigners in China is driven by Chinese patenting and by other foreign inventors patenting in China $\mathrm{Hu}$ and Mathews, 2008, $\underline{\mathrm{Hu}, 2010}$ ). Furthermore, the literature overview in Section 2 highlighted that government policies supporting innovation and technology transfer are key elements in explaining trade flows and the rapid development of the solar PV and wind energy industry in China. Building upon this literature, we expect that both R\&D spending and foreign and national knowledge are related to respective technology exports. Following 
the classification by Johnston et. al (2010), based on the International Patent Classification (IPC) system and Dechezleprêtre (2010, 2011) to differentiate between foreign and national knowledge, we obtain solar PV and wind energy patent data from the European Patent Office's Worldwide Patent Statistical database (EPO, 2010). Similar to

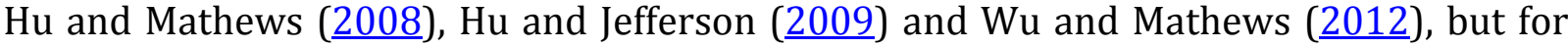
solar PV and wind energy technologies, the data show that patenting activity began to surge in the early 2000s (Figure 7) ${ }^{3}$.

Figure 7: Foreign and national patent applications and knowledge stock for solar PV and wind energy technology in China

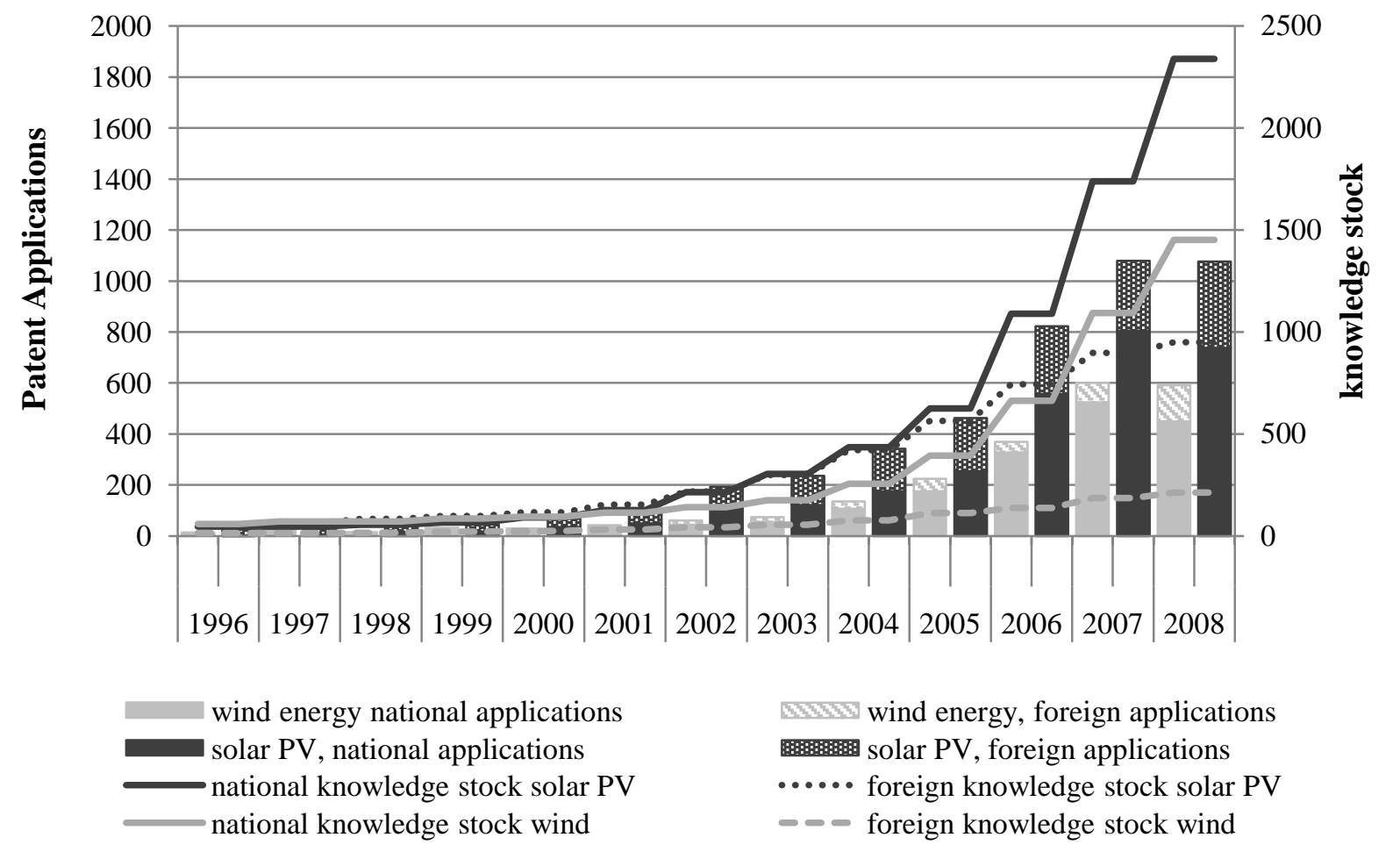

Sources: Patent Applications authors' calculations based on EPO PATSTAT 2010 Note: Number of patent applications in fractional counts to avoid duplications, knowledge stock calculation is based on a depreciation rate of 0.15 .

${ }^{3}$ See also Section 4.1 and Appendix 5 for a more detailed outline of this approach. In order to avoid duplicates the number of patent families is counted. Knowledge stock is calculated using a depreciation rate of 0.15 . The number of total patent applications has been cross checked with the Chinese State Intellectual Property Office (SIPO). 
The total number of patents applied for both technologies by foreign and Chinese inventors increased rapidly. With respect to solar PV innovation, the data show that 88 percent of patents applied for in China in 1996 were invented by foreigners. This figure decreased to 48 percent in 2000 and 31 percent in 2008. Innovation and foreign technology transfer in wind energy technology experienced a similar development, although foreign knowledge in terms of patent applications initially played a smaller role in 1996 accounting for only 32 percent in 1996 and 24 percent in 2008. The subsequent increasing gap between national and foreign knowledge is in line with findings highlighting a shift from imitation and cooperation to indigenous innovation.

\section{Empirical framework: gravity model for trade analysis}

Section 3.1 described the development and structure solar PV and WETC trade highlighting that the majority of Chinese exports is imported by high income OECD countries. In fact, approximately 70 percent of Chinese solar photovoltaic (PV) component exports in 2008 were imported by six countries: Germany, the US, Japan, Korea, Italy, and Spain. The empirical trade flow analysis to identify determinants of trade generally adopts a gravity model. Accounting for the different potential drivers, such as those highlighted in Sections 3.2 and 3.3 and further described in Section 5, that go beyond standard trade determining variables, we adopt an augmented gravity model as follows:

$$
X_{i j t}=\beta_{0}\left(\frac{Y_{i t}^{\beta_{1}} Y_{j t}^{\beta_{2}} Z_{i j t}^{\beta_{n}}}{D_{i j}^{\beta_{3}}}\right) \eta_{i j t}
$$

where $X_{i j t}$ is the dependent variable describing specific technology export flows between destination country $i$ and exporting country $j$, i.e. China, as a function proportional to economic mass $(Y)$, a suite of additional explanatory variables $(Z)$ and inversely proportional to trade costs such as distance $(D)$. Based on work of Tinbergen $(\underline{1962})$, the model gives a generally successful empirical performance and its theoretical foundations are strong (Anderson, 1979, Bergstrand, 1985, 1989, Feenstra et al., 2001, Jug and Mirza, $\underline{2005}$ Anderson and van Wincoop, 2003). The generally utilized empirical specification of the gravity model reads as follows: 


$$
\ln X_{j i t}=\beta_{0}+\beta \ln Y_{i t}+\beta \ln Y_{j t}-\beta \ln D_{j i}+\beta_{4} \ln Z_{i j t}+\eta_{i j t}
$$

$$
\text { with: } \quad \eta_{i j t}=\delta_{i t}+\alpha_{i}+\varepsilon_{i j t}
$$

A similar specification is adopted in earlier work identifying the determinants of Chinese trade (Edmonds et al., 2008, Rodrik, 2006). Using panel data facilitates the recognition of how relevant variables evolve over time as well as identifying time or country specific effects. Proper estimation of this model when small sectoral trade flows are analyzed, as done is this study, requires taking several issues regarding econometric specification and panel data characteristics into consideration. Standard ordinary least square estimation (OLS) yields biased coefficients as the framework is subject to unobserved heterogeneity (Hsiao, 2003). A common remedy is the employment of random or fixed effects $\alpha_{\mathrm{i}}$. While the fixed effects estimator controls for time constant unobserved heterogeneity between countries, the random effect estimation assumes exogeneity and imposes no correlation between individual effects and the repressors. This assumption is likely to be invalid, yielding inconsistent estimates as various country specific characteristics that influence import and export behavior are neglected. Using Hausman tests, we show that the null hypothesis of zero correlation between unobserved effects and the dependent variable is rejected; implying that fixed effect estimation is advisable. Additionally, the results LR, LM and F-tests confirm that unobserved heterogeneity is present, indicating that individual effects $\alpha_{i}$ and country specific time trends $\delta_{\mathrm{t}}$ are required. By including these time-invariant and time-variant importing country specific effects we not only control for heterogeneity but also for multilateral trade resistance between China and its trading partners (Anderson and van Wincoop, $\underline{2003}$ Baldwin and Taglioni, 2006). A remedy is that interesting time invariant variables such as distances are dropped from estimation.

\subsection{Frequent zero trade flows and overdispersion}

A major source of inconsistency arises under the presence of zero trade flows and log-transformation in the gravity equation under OLS estimation. As the log of zero is not defined, information is lost rendering biased estimates and a loss in efficiency. Zero trade flows, however, are quite common when analyzing bilateral trade data and are frequent 
in datasets of sector specific trade flows. Frankel (1997) outlines several widely applied approaches ranging from omitting zero trade flows to replacing them with arbitrarily small numbers or adding one when taking logs. However, each of these approaches suffers from arbitrary data modification and might be subject to sample selection biases as the zeros are not randomly distributed (Westerlund and Wilhelmsson, 2008).

A robust alternative drawing attention in literature is the Poisson pseudomaximum likelihood estimator (PPML), proposed by Santos Silva and Tenreyro (2006). This level-log retains the dependent variable in levels while right hand side variables remain logarithmized. Therefore, the zero problem is solved and the estimated gravity equation is given as:

$$
X_{j i t}=\beta_{0}+\beta \ln Y_{i t}+\beta \ln Y_{j t}-\beta \ln D_{j i}+\beta_{4} \ln Z_{i j t}+\delta_{i t}+\alpha_{i}+\varepsilon_{i j t}
$$

Santos Silva and Tenreyro (2006) and Winkelmann (2008) argue that Poisson estimation of non-count data is robust against potentially remaining heteroskedasticity and measurement errors in the log transformed right hand side variables thus being more adequate than models assuming homoskedasticity. However, Poisson estimation poses another problem. A violation of the equidispersion condition in the Poisson model not guaranteeing the proportionality condition $E(Y / X)=\operatorname{Var}(Y / X)$, does not allow for adequate estimation (Wooldridge, 2002). In our data we find an increasing ratio of the variance to the conditional mean. Hence overdispersion is present, which requires Negative Binominal Regression Model (NBREG) to properly estimate coefficients while allowing the inclusion of zero trade flows (Cameron and Trivedi, 2005 Amiti and Freund, 2010). ${ }^{4}$ But negative binominal models controlling for unobserved heterogeneity through country specific dummies yields consistent maximum likelihood estimates only under strict assumptions as the number of incidental parameters is increasing with sample size

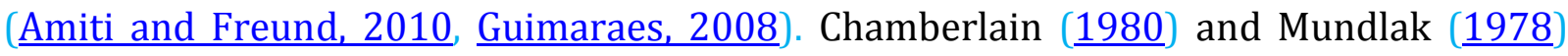

\footnotetext{
${ }^{4}$ In this case, we conducted a likelihood ratio test on the Poisson and the negative binominal distribution on each cross-section section. The test rejects the null hypothesis of equivalence pointing toward overdispersion.
} 
provide an alternative to fixed effects by including averages of time-varying country specific explanatory variables. ${ }^{5}$ We adopt this approach to properly control for present fixed effects such that:

$$
\overline{\alpha_{\imath}^{Y_{l t} ; Y_{j t} ; Z_{l \jmath t}}}=\frac{1}{t} \sum_{t=1}^{t}\left(Y_{i t} ; Y_{j t} ; Z_{i j t}\right) \quad \text { for } i=1,2, \ldots, N
$$

\subsection{China: respecting individual non-variant time series variables and multicollinarity}

Standard gravity model studies usually analyze a panel of bilateral trade between multiple importer and exporter countries. In our case we aim at determining drivers of trade between multiple importing countries and only one exporting country. By introducing control variables for Chinese economic development, policy effects and innovation, as specified in the following section, we include variables that vary over time but not across individuals. In this study, these variables are highly but not perfectly correlated potentially causing statistical problems such as high standard errors even under joint significance, implausible coefficient magnitudes and signs (Green, 2002). In order to reduce multicollinarity issues, control variables for China enter the regression in differences. ${ }^{6}$

\subsection{Final model specification}

We estimate the Fixed Effects OLS model, the PPML as well as the NBREG models. Even though Santos Silva and Tenreyro (2006) outline that Poisson estimation of noncount data is robust against remaining heteroskedasticity, we expect the NBREG model to yield consistent and efficient estimates as overdispersion is controlled for (Wooldridge,

\footnotetext{
${ }^{5}$ See also Wooldridge (2010), for an empirical applications see Bergstrand, Egger, Larch (2011)

${ }^{6}$ An alternative to this approach is estimation in first differences. However, this poses several other problems as first differencing neglects zero trade flows or introduces infinite growth rates with zero observations early in the period analyzed. Furthermore, the interpretation of policy dummy control variables changes from the effect of the existence of these policies to the effect of the introduction of these policies.
} 
2002). Including the variables of interest that will be described in the subsequent section and respecting estimation issues outlined above our final estimation model is described as follows:

$$
\begin{aligned}
X_{\text {China } t}=\beta_{0} & +\beta \ln Y_{i t}+\beta_{2} P_{i t}+\beta_{3} \ln M_{i t}+\beta_{4} \ln I_{i \text { Chinat }}+\beta_{5} \Delta \ln Y_{\text {China } t} \\
& +\beta_{6} \Delta \ln P_{\text {China }}+\beta_{7} \Delta \ln I_{\text {China } t}-\beta_{8} \ln T_{\text {i China } t}-\beta_{9} \ln D_{\text {i China }} \\
& +\delta_{i t}+\alpha_{i}+\varepsilon_{i j t}
\end{aligned}
$$

and according to (4) with:

$$
\alpha_{i}=\beta \ln \bar{Y}_{l}+\beta_{11} \ln \bar{T}_{l}+\beta_{12} \ln \overline{I_{l}}+\beta_{13} \ln \overline{M_{l}}+\beta_{14} \bar{P}_{l}
$$

where $\beta_{0}$ is a constant term, $\ln Y_{i t}$ and $\Delta \ln Y_{\text {China } t}$ represent the economic mass of importing countries and the respective growth in China; $Z_{i j t}$ from (3) has been replaced by a suit of binary variables representing policies in importing countries that promote renewable energy utilization $\left(P_{i t}\right)$, market size of renewable energy equipment in terms of electricity generated from either solar PV or wind energy $\left(\ln M_{i, s, t}\right)$, importing country stock of knowledge available in China $\left(\ln I_{i \text { China } t}\right)$ and controls for growth in $R \& D$ appropriation policy $\left(\Delta \ln P_{\text {China } t}\right)$ and technology specific knowledge stock in China $\left(\Delta \ln I_{\text {China } t}\right)$ as described in Section; $D_{i j}$ representing trading costs in (3) is divided into distance between China and the importing country $\left(\ln D_{i \text { China }}\right)$ and effectively applied tariffs of the importing country on imports from China $\left(\ln T_{i \text { China } t}\right)$. Finally, $\delta_{i t}$ represent country specific trends and $\alpha_{i}$ represent country fixed effects canceling out unobserved heterogeneity, thus reducing endogeneneity. Consequently, an independent idiosyncratic error $\varepsilon_{i j t}$ remains. In the NB estimation specification these country specific effects are approximated using the Chamberlain-Mundlak approach of mean differencing. Both, fixed effect and country specific time trends play a key role when controlling for heterogeneity as discussed earlier. 


\section{$5 \quad$ Trade determining variables and data}

The gravity model is implemented using annual data of panel of 43 importing countries for the period 1996-2008 accounting for 90 percent of solar PV and wind energy technology component exports from China in 2008. Although, we would like to extend the analysis to incorporate more recent developments, the availability of data permits us to focus only on the period from 1996 to 2008.

\subsection{Socioeconomic variables}

Economics mass in gravity trade studies is generally control for by using socioeconomic country characteristics such as income and population. The standard gravity literature points out that a country's income is positively related to the bilateral trade volume? Furthermore, according to the environmental Kuznets curve theorem, demand preferences for environmental products increase with income (Dinda, 2004). Therefore, we expect income per capita to positively affect imports of solar PV and wind energy technology components. Following Frankel (1997), we include GDP per capita as explanatory variable in order to control for the relationship between higher income and increasing trade flows of more capital intensive products such as those analyzed here. Another mass variables used in the literature is the area of importing countries which is expected to positively affect trade. In our context, country size in terms of area can also be seen as a proxy for renewable energy potential. Data for each of the variables is obtained from the World Development Indicator (WDI) and the Centre d'Etudes Prospectives et d'Informations Internationales (CEPII).

\subsection{Trade costs and trade barriers}

Trade costs play a significant role in determining trade flows between countries. Hence we include distance between economic centers, which is expected to negatively affect trade as additional costs are induced, and the actual level of trade barriers measured in terms of tariffs effectively applied on Chinese solar PV and wind energy components by

\footnotetext{
${ }^{7}$ For an extensive discussion on standard determinants of bilateral trade see Frankel (1997) and Balassa (Balassa, 1969).
} 
importing countries. As data on nontariff barriers to be introduced in a cross-country study, this variable serves as standard proxy for the level of trade restrictions. ${ }^{8}$ We expect that higher import duties will reduce imports as higher costs are associated. Figure 8 shows that the mean import tariff applied on import of WETC from China is lower than tariffs imposed on solar PV components. Mean import tariffs for both technology segments have been decreasing in the past decade, suggesting that this reduction is in line with increasing imports.

Figure 8: Mean effectively applied tariffs on imports of solar photovoltaic and wind energy technology components from China

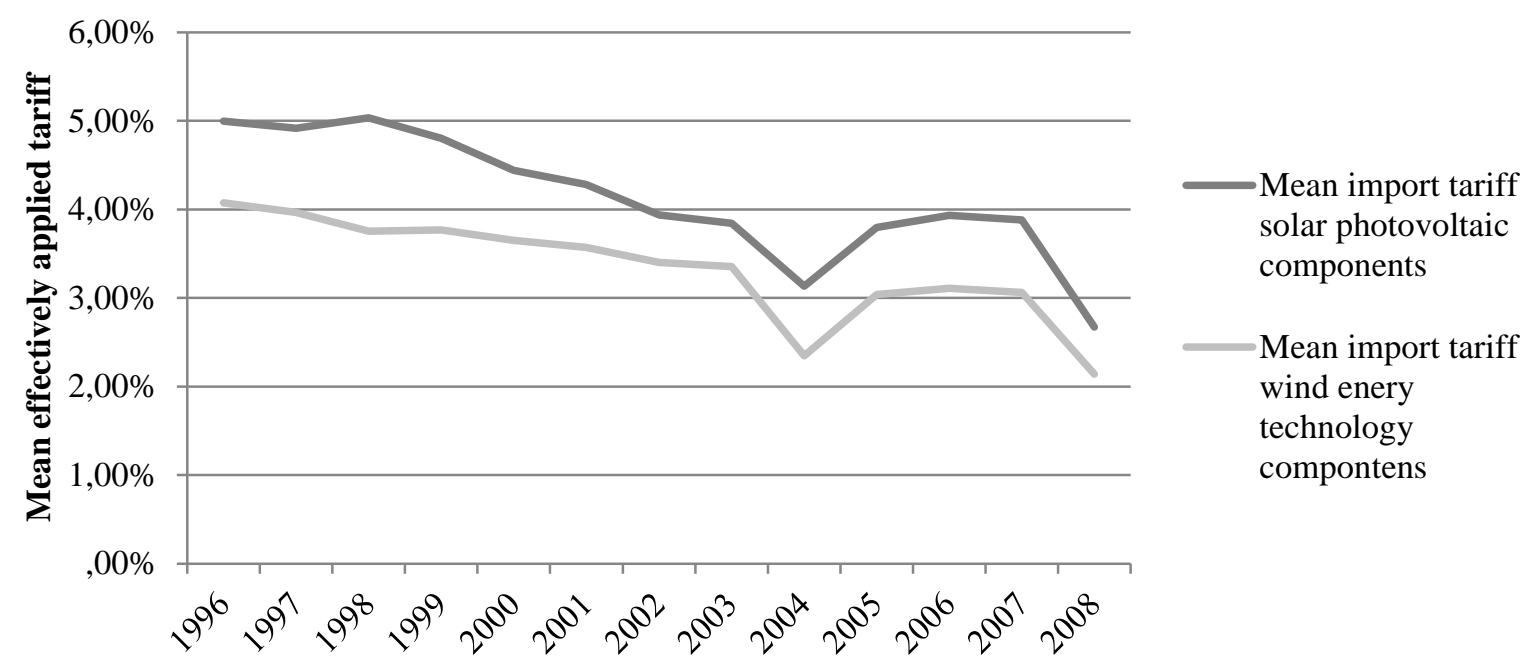

Note: based on the sample of 43 importing countries. Source: authors' calculations based on UNCTAD TRAINS database

The dent of below 1 percent in 2004 is explained by using the tariff applied by the EU to obtain tariffs by EU member countries which do not report individual tariff levels. Yet, the accession of several Central and Eastern European countries to the European

\footnotetext{
${ }^{8}$ Several studies outline the importance of non-tariff barriers to trade with environmental goods such as those analysed here. Alavi (2007) shows that non-tariff barriers such as local content, tied in aid and a lack of standards for certification and approval of projects are major barriers for wind energy technology trade. Fliess and Kim (2008) highlight that environmental industry cost-raising factors pose greater problems due to limited resources of small and medium sized companies that are commonly active in the sector.
} 
Union in 2004 raised the mean tariff applied due slower adoptions of EU level import tariffs. This could lead to mixed results as imports were increasing at the same time. However, introducing tariff barriers into the analysis allows us to understand potential effects of increasing tariffs, which were discussed in the US and the EU in early 2012. Data for technology specific import duties in importing countries are obtained from the UN TRAINS databank using the respective HS classifications (Appendix 1).

\subsection{Market size and policies promoting renewable energies}

In order to capture the market size for renewable energy technology components in importing countries \& China, we use the amount of electricity generated (in Million KWh) from solar PV and wind energy. We assume that a large amount of electricity generation from each source corresponds to a high demand of, and thus a large market for, each of the respective technologies components. Consequently, imports are expected to be higher in countries that generate relatively more solar PV and wind energy electricity. ${ }^{9}$ Data is obtained from the EIA (2012) International Energy Statistics. We also include support policy schemes promoting renewable energies utilization in importing country to control for policy type and market structure to some extent. The importance of these supply side policies for electricity generation and innovation is emphasized in the literature (Popp et al., 2011, IEA, 2004 Lohnstone et al., 2010). Constantini and Crespi (2008) outline the role of environmental regulation on trade with energy technology components. Yet, the effect that specific renewable energy policies have on trade has not been assessed. We introduce dummy variables for (1) incentive tariffs, (2) obligations and (3) tax measures. Time of enactment information is collected from the IEA/IRENA (2011) Global Renewable Energy Policies and Measures Database. Incentive tariffs are summarized as guaranteed price systems, feed-in tariffs and bidding systems promoting the use of renewable energies. Obligations require suppliers to provide a specific production

\footnotetext{
${ }^{9}$ A potential limitation on the feasibility of this variable is the issues of endogeneity as increasing renewable energy generation can also be caused by increased imports of respective technologies. However, this is a feasible way of measuring regulatory output. Nevertheless, we have conduct robustness checks with this variable lagged by one period and results remain robust. Therefore, we assume that endogeneity is not a problem.
} 
quantity or percentage from renewable sources through portfolio standards, quota systems or targets. Tax measures summarize different policies, such as production and investment tax credits and property tax exemptions favoring renewable energy utilization. Table 2 displays the enactment of these policy types in the countries analyzed. Policy enactment is considerably skewed over time as some countries introduced these policies early while others lagged behind. Interestingly, countries that have an especially high share of component imports from China, such as Germany and the US, also have relatively large markets, measured as electricity generation from renewable sources, and introduced such policies early in the 1990s while those that only trade marginally with China implemented respective policies only after the turn of the century. However, policy strength and policy design are of each of the three policies are different across countries. Therefore, a caveat of the analysis is that we cannot measure those differences as only data on policy enactment is available.

Table 2: Years of renewable energy policy enactment in the sample of 43 countries from 1996 - 2008

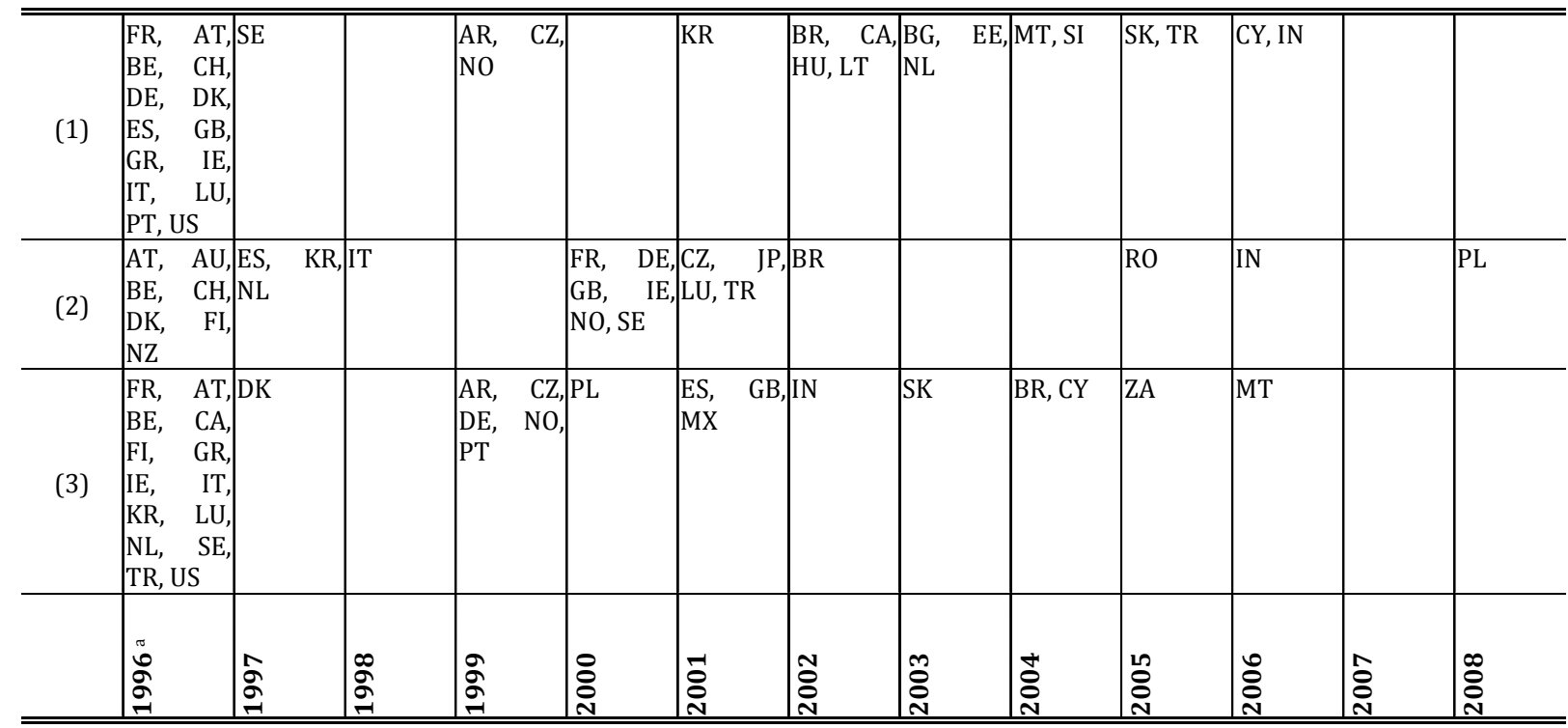

Notes: Each row represents a renewable energy supportive policy type implemented in the respective country: (1) Incentive Tariffs (2) obligations (3) tax measures. (a) Policies implemented in 1996 or before. Countries (ISO): $A R$ Argentina, AT Austria, AU Australia, BE Belgium, BG Bulgaria, BR Brazil, CA Canada, CH Switzerland, CY Cyprus, CZ Czech Republic, DE Germany, DK Denmark, EE Estonia, ES Spain, FI Finland, FR France, GB United Kingdom, GR Greece, HU Hungary, ID Indonesia, IE Ireland, IN India, IS Iceland, IT Italy, JP Japan, KR Korea, $L T$ Lithuania, LU Luxembourg, LV Latvia, MT Malta, MX Mexico, NL Netherlands, NO Norway, NZ New Zealand, PL Poland, PT Portugal, RO Romania, RU Russia, SE Sweden, SI Slovenia, SK Slovak Republic, TR Turkey, US United States, ZA South Africa; Sources: IEA/IRENA (2011) Global Renewable Energy Policies and Measures Database; REN21 (2011) Renewables 2011 Global Status Report. 
Section 3 highlighted that supply side policy in China has been lagging behind the development in other countries and that the electricity generated from solar PV remained low until 2008, while that of wind energy increased substantially after 2005. Along econometric issues presented in Section 4 we include electricity generation growth from solar PV and wind energy sources in China as a control for environmental regulation or market size and its effect on determining exports. We believe, that an increasing national market might be paralleled by the development of an industry that can also increasingly target international markets as observed in Germany for instance. Yet, on the contrary, a growing national market for solar PV and wind energy components in China could also negatively affect exports as increased national demand for components could be satisfied through national production. In order to test the potential impact we include the lagged growth of solar and wind electricity generation to allow inertia in industry development.

\section{$5.4 \quad R \& D$, knowledge and technology transfer}

The literature overview shows that $R \& D$, knowledge adoption capabilities, technology transfer and innovation play an important role in facilitating bilateral trade. In Section 3.2 we show that $R \& D$ appropriations in China at the national and provincial level directed at renewable energies increased substantially. We expect increased spending, considered to be a technology push policy, to have a positive trade effect. Section 3.3 points out that patent applications in China surged after 2000, both in total patents and, in particular, patents on solar PV and wind energy technologies. Using patent data the interest of this analysis is twofold. First, we want to identify the role foreign knowledge plays in explaining Chinese exports and whether or not China exports clean technologies to countries that have previously transferred knowledge to China. Second, we aim at understanding the role of Chinese inventiveness in the process of enabling the country to access new markets.

Following the innovation and knowledge spillover literature we introduce two variables to estimate the effect of innovation and knowledge transfer in green technologies.

First, the knowledge stock variable based on patents by inventors from each importing country applied for protection in China is used as a proxy for available foreign knowledge. We expect transfers of knowledge in these sectors to have a positive impact 
on imports, as both technology design and production knowledge might have been exported through patents in order to secure future profits in a growing market or for gaining production cost advantages. This expectation is strengthened by a descriptive analysis which, however, also highlights differences between technologies. Countries that contributed most to solar PV technology specific foreign knowledge in China are also among the top ten importers of solar PV components from China. A slightly different picture emerges when looking at technology transfer and imports of wind energy technology components. The market is much smaller and emerging markets, such as India and Indonesia, are among the top ten importers even though they have only marginally transferred knowledge to China (Table 3).

Table 3: Top 10 countries in terms of technology transfer to China and solar energy component imports from China

\begin{tabular}{|c|c|c|c|c|c|c|c|c|c|}
\hline \multicolumn{5}{|c|}{ Technology Transfer Stock to China ${ }^{(1)}$} & \multicolumn{5}{|c|}{ Imports Technology Components from China } \\
\hline & 1996 & 2000 & 2004 & 2008 & (Mio US \$) & 1996 & 2000 & 2004 & 2008 \\
\hline \multicolumn{10}{|c|}{ Solar PV technology } \\
\hline Japan & 22.2 & 57.2 & 261.7 & 558.5 & Spain & 3 & 6 & 18 & 4200 \\
\hline United States & 10.9 & 29.3 & 74.7 & 159.2 & Germany & 23 & 67 & 388 & 3700 \\
\hline Germany & 2.8 & 9.1 & 28.1 & 84.0 & United States & 199 & 382 & 863 & 2300 \\
\hline Korea & 1.8 & 5.7 & 18.3 & 65.3 & Japan & 115 & 388 & 700 & 1400 \\
\hline Netherlands & 0.5 & 0.8 & 4.2 & 11.8 & Korea & 6 & 36 & 220 & 1100 \\
\hline France & 0.3 & 1.7 & 4.5 & 6.9 & Italy & 8 & 15 & 62 & 884 \\
\hline Switzerland & 4.8 & 5.1 & 4.3 & 6.3 & Netherlands & 6 & 26 & 145 & 847 \\
\hline Australia & 0.4 & 1.3 & 4.2 & 5.1 & India & 0 & 7 & 46 & 543 \\
\hline United & & & & & & & & & \\
\hline Kingdom & 1.7 & 2.0 & 3.7 & 4.5 & Belgium & 0 & 5 & 37 & 459 \\
\hline Italy & 0.1 & 0.4 & 3.4 & 3.7 & France & 18 & 51 & 82 & 363 \\
\hline \multicolumn{10}{|c|}{ Wind energy technology } \\
\hline United States & 4.1 & 4.4 & 13.0 & 57.9 & United States & 2 & 26 & 74 & 352 \\
\hline Germany & 1.0 & 3.8 & 12.7 & 37.3 & India & 0 & 0 & 2 & 230 \\
\hline Japan & 3.0 & 5.8 & 18.5 & 30.3 & Japan & 8 & 15 & 45 & 183 \\
\hline Denmark & 0.0 & 1.7 & 10.1 & 20.8 & Indonesia & 2 & 11 & 18 & 63 \\
\hline Spain & 0.0 & 0.1 & 1.4 & 13.3 & Korea & 1 & 0 & 10 & 42 \\
\hline Korea & 0.1 & 1.9 & 3.9 & 6.6 & Germany & 0 & 3 & 12 & 31 \\
\hline United & & & & & & & & & \\
\hline Kingdom & 0.5 & 0.4 & 3.3 & 4.9 & Turkey & 0 & 1 & 7 & 28 \\
\hline France & 0.2 & 0.3 & 0.5 & 4.5 & Italy & 0 & 1 & 7 & 26 \\
\hline Italy & 0.2 & 0.2 & 1.3 & 3.8 & Australia & 1 & 5 & 5 & 22 \\
\hline Canada & 0.0 & 0.0 & 1.7 & 3.6 & Canada & 1 & 1 & 8 & 21 \\
\hline
\end{tabular}

Notes: (1) Knowledge stock based on fractional patent counts and a depreciation rate of 0.15, initial knowledge stock based on 1980. Sources: OECD/EPO Patstat Database, UNCTAD Comtrade Database, Authors calculation. 
Second, we identify the role of the development of Chinese innovations by introducing the national knowledge stock growth based on patent applications by Chinese in China. Contrary to using only annual patent applications counts, the knowledge stock approach accounts for previous knowledge, which is important to determine innovation success. We expect that increasing national knowledge stock has a positive effect on Chinese exports, as would be in line with the literature outlined above.

More detailed information on these two variables is presented in Appendix 1. Growth in $R \& D$ appropriation and knowledge stock in China are lagged by one period to account for technology transition inertia from innovation to market readiness. Using both an innovation input measure in terms of $R \& D$ spending and an output measure in terms of patents, might pose difficulties due to multicollinearity. Yet, we use both controls only lagged once which is likely to reduce this problem as R\&D spending in one period will not immediately affect research output in that period but only in later periods. Additionally, endogeneity is avoided.

\section{Results}

The subsequent tables present results for different estimation models on total exports (Table 4), solar PV (Table 5) and wind energy technology component exports (WETC) (Table 6) from China to the sample of 43 importing countries. Estimation results on total exports highlight that the model is correctly specified. These results serve as benchmark for show coefficient size and effects of general trade determining variables also used in the remaining sectoral trade estimations and corresponding model specifications. In terms of total exports, the log-likelihood indicates that the Fixed Effects Ordinary Least Square (FE) estimation is preferred over Poisson (PPML) and negative binominal estimation (NB) as zero trade flows and overdispersion are not present. In the FE estimation $95 \%$ of variance are explained by the selected predictors. In this specification a one percent increase in per capita income in importing countries has a trade increasing effect of 3.7 percent. Distance and area are omitted due to fixed effects estimation which drops time-invariant controls. While GDP per capita has a comparable coefficient, the NB speciation using the Chamberlain-Mundlak fixed effects approach indicates that a 
doubling of distance has a trade decreasing effect of 95 percent, while the area of importing countries has a trade increasing effect as expected. Furthermore, in the FE specification, a one percent increase of Chinese income per capita growth increases exports by 3 percent. The results indicate that the model is calibrated correctly, as the standard control variables have the expected sign and significance and are thus in line with earlier findings (Edmonds et al., 2008).

Table 4: Preliminary Total imports from China estimation results

\begin{tabular}{|c|c|c|c|}
\hline & $\begin{array}{l}(1) \\
\mathbf{F E}\end{array}$ & $\begin{array}{c}(2) \\
\text { PPML }\end{array}$ & $\begin{array}{l}(3) \\
\text { NB }\end{array}$ \\
\hline GDP per capita it, ln & $\begin{array}{r}3.74^{* * *} \\
(0.69)\end{array}$ & $\begin{array}{r}1.95^{* * *} \\
(0.65)\end{array}$ & $\begin{array}{r}3.81^{* * *} \\
(0.30)\end{array}$ \\
\hline distance $_{\text {i-china }}, \ln$ & & & $\begin{array}{r}-0.95^{* * *} \\
(0.15)\end{array}$ \\
\hline area $_{i}, \ln$ & & & $\begin{array}{r}0.31^{* * *} \\
(0.03)\end{array}$ \\
\hline import tariff it china s, $\ln$ & $\begin{array}{r}-0.07 \\
(0.05)\end{array}$ & $\begin{array}{l}-0.00 \\
(0.05)\end{array}$ & $\begin{array}{r}-0.02 \\
(0.02)\end{array}$ \\
\hline$\Delta$ GDP per capita Chinat, $\ln$ & $\begin{array}{r}3.00^{* * *} \\
(0.88)\end{array}$ & $\begin{array}{r}1.77^{* * *} \\
(0.63)\end{array}$ & $\begin{array}{c}0.75^{*} \\
(0.40)\end{array}$ \\
\hline Constant & $\begin{array}{r}-23.67^{* * *} \\
(6.68) \\
\end{array}$ & & $\begin{array}{r}0.55 \\
(1.94) \\
\end{array}$ \\
\hline country fixed effects & Yes & yes & $\begin{array}{c}\text { Chamberlain/ } \\
\text { Mundlak }\end{array}$ \\
\hline country trend & Yes & yes & yes \\
\hline $\mathrm{N}$ & 516 & 516 & 516 \\
\hline r2 & 0.956 & & \\
\hline Wald chi2 & & 46.03 & $16,471.70$ \\
\hline$P$ & & 0.47 & 0.00 \\
\hline $\mathrm{Ll}$ & 67.06 & $-20,974,077$ & $-6,528.22$ \\
\hline
\end{tabular}

The first three columns of Table 5 present the same model specification as in Table 4 for solar PV exports from China. Compared to the results estimating total trade, size and significance level of coefficients differ in magnitude to some degree but major features of the gravity model are confirmed throughout the analysis. The fixed effects (FE) model in Specification (1) does not adequately taking into account zero trade flows, which represent 14 percent of the observations. Thus, it is likely to be inconsistent as it is based on manipulated data of the dependent variables $(\ln +1)$. The alternative estimation 
procedure (PPML) in Specification (2) is also likely to be biased even though it controls for zero trade flows and heteroskedasticity as data is characterized by considerable overdispersion. The log likelihood values indicate that the model fit improves considerably when using NB instead of PPML.

The baseline model is likely to be subject to an omitted variable bias. Consequently, Specifications (4)-(6) extend the baseline model by introducing control variables capturing market size for solar PV components, renewable energy policy support schemes in importing countries and technology specific knowledge transfer from importing countries to China. Specifications (7)-(16) additionally introduce controls for policy development in China in terms of R\&D appropriation growth and national knowledge stock development as well as renewable energy market development in China. To the extent that there might be multicollinearity between R\&D efforts and the knowledge stock in China, we estimate these variables separately in Specifications (11)(16). Most coefficients are robust across different model specifications.

The preferred NB model shows that a one percent increase in importing country per capita income yields an increase of solar PV component imports of 4.5 percent (Specification 3) to 3.6 percent (Specification 16). As suggested by theory, distance has a significant negative impact on trade in the baseline model outlining that a doubling of distance decreases trade by 137 percent in Specification 3. Yet, including further controls reduces this effect considerably and the coefficient becomes insignificant. The coefficient on technology specific import tariffs is negative and significant in Specifications (6), (9), (13) and (15) Yet, a one percent increase in tariffs decreases trade only by 0.05 percent.

The strongly significant coefficient on solar PV electricity generation in destination markets indicates that a one percent increase in market size in importing countries is estimated to increase respective imports from China between 2.76 percent (Specification 6) and 1.8 percent (Specification 9). 
1 Table 5: Estimation results for imports of solar photovoltaic components from China

\begin{tabular}{|c|c|c|c|c|c|c|c|c|c|c|c|c|c|c|c|}
\hline & \multicolumn{3}{|c|}{ Baseline } & \multicolumn{3}{|c|}{ Market and Policies in $i$} & \multicolumn{9}{|c|}{ Full Model } \\
\hline & (1) & (2) & (3) & (4) & (5) & (6) & (7) & (8) & (9) & (11) & $(12)$ & (13) & (14) & (15) & (16) \\
\hline & FE & PPML & NBREG & FE & PPML & NBREG & FE & PPML & NBREG & FE & PPML & NBREG & FE & PPML & NBREG \\
\hline \multirow{2}{*}{ GDP per capita ${ }_{\text {it }}, l n$} & 2.27 & 1.09 & $4.50 * * *$ & 2.84 & -0.02 & $4.54 * * *$ & 3.02 & $1.31^{*}$ & $3.41 * * *$ & 2.88 & $1.48^{*}$ & $4.69 * * *$ & 2.91 & $1.65^{*}$ & $3.61 * * *$ \\
\hline & (1.89) & (1.50) & $(0.60)$ & (2.01) & $(0.99)$ & $(0.61)$ & (1.91) & $(0.79)$ & $(0.72)$ & (1.92) & $(0.82)$ & $(0.74)$ & (1.84) & $(0.86)$ & $(0.72)$ \\
\hline \multirow[t]{2}{*}{ distance $_{\text {i-china }}, \ln$} & & & $-1.37 * * *$ & & & -0.30 & & & -0.05 & & & -0.17 & & & -0.30 \\
\hline & & & $(0.27)$ & & & $(0.30)$ & & & (0.33) & & & $(0.32)$ & & & $(0.33)$ \\
\hline \multirow[t]{2}{*}{ area $_{i}, \ln$} & & & $0.70^{* * *}$ & & & $0.55 * * *$ & & & $0.51^{* * *}$ & & & $0.51^{* * *}$ & & & $0.53 * * *$ \\
\hline & & & $(0.05)$ & & & $(0.08)$ & & & $(0.08)$ & & & $(0.08)$ & & & $(0.08)$ \\
\hline \multirow{2}{*}{ import tariff ${ }_{\text {it china s }}, \ln$} & -0.05 & 0.03 & -0.01 & -0.07 & 0.01 & $-0.04 * *$ & -0.07 & 0.00 & $-0.06 * * *$ & -0.07 & 0.01 & $-0.05 * *$ & -0.06 & 0.01 & $-0.05 * * *$ \\
\hline & $(0.07)$ & $(0.04)$ & $(0.02)$ & $(0.07)$ & $(0.03)$ & $(0.02)$ & $(0.08)$ & $(0.03)$ & $\quad(0.02)$ & $(0.07)$ & $(0.03)$ & $(0.02)$ & $(0.07)$ & $(0.03)$ & $\quad(0.02)$ \\
\hline \multirow[t]{2}{*}{$\Delta$ GDP per capita China, $\ln$} & 6.10 & -0.73 & $1.42 *$ & 5.80 & 1.33 & $1.74 * *$ & 3.56 & 1.05 & 1.74 & 3.63 & -0.31 & 0.79 & 5.71 & 1.30 & $2.20^{*}$ \\
\hline & (3.95) & (2.03) & $(0.74)$ & (3.86) & (1.48) & $(0.88)$ & (4.19) & (1.15) & (1.53) & $(4.12)$ & (1.35) & (1.51) & (3.84) & (1.42) & (1.33) \\
\hline \multirow[t]{2}{*}{ electricity gen $_{\text {it s }}, \ln$} & & & & $2.28 * * *$ & $0.40^{* * *}$ & $2.76 * * *$ & $2.34 * * *$ & $0.26 * *$ & $1.83^{* * *}$ & $2.33 * * *$ & $0.27 * *$ & $2.04 * * *$ & $2.27 * * *$ & $0.32 * *$ & $1.91 * * *$ \\
\hline & & & & $(0.46)$ & $(0.14)$ & (0.43) & $(0.36)$ & $(0.13)$ & $(0.42)$ & (0.35) & $(0.12)$ & $(0.40)$ & (0.34) & $(0.14)$ & $(0.42)$ \\
\hline \multirow[t]{2}{*}{ tax measures it } & & & & 0.30 & $-0.36 *$ & -0.02 & -0.04 & -0.23 & 0.00 & -0.03 & -0.26 & 0.10 & -0.00 & -0.30 & -0.06 \\
\hline & & & & $(0.29)$ & $(0.19)$ & $(0.12)$ & $(0.27)$ & $(0.21)$ & $(0.13)$ & $(0.26)$ & $(0.21)$ & $(0.13)$ & $(0.27)$ & $(0.2$ & $(0.13)$ \\
\hline \multirow[t]{2}{*}{ incentive tariffs it } & & & & 0.72 & $0.36^{*}$ & $0.28 * *$ & 0.55 & $0.41 * *$ & $0.33 * * *$ & 0.55 & $0.42 * * *$ & $0.36 * * *$ & 0.57 & $0.38^{* *}$ & $0.30 * *$ \\
\hline & & & & $(0.46)$ & $(0.21)$ & $(0.12)$ & $(0.45)$ & $(0.16)$ & $(0.13)$ & $(0.45)$ & $(0.16)$ & $(0.13)$ & $(0.45)$ & $(0.18)$ & $(0.12)$ \\
\hline \multirow[t]{2}{*}{ obligations it } & & & & $-0.50 *$ & $-0.37 * * *$ & -0.11 & $-0.49 *$ & $-0.21 * *$ & -0.10 & $-0.47 *$ & $-0.29 * * *$ & -0.12 & $-0.45^{*}$ & $-0.31 * * *$ & -0.07 \\
\hline & & & & $(0.27)$ & $(0.10)$ & $(0.10)$ & $(0.25)$ & $(0.09)$ & $(0.10)$ & $(0.26)$ & $(0.10)$ & $(0.10)$ & $(0.24)$ & (0.09) & $(0.10)$ \\
\hline \multirow[t]{2}{*}{ Tech Transfer ${ }_{i \text { china s } t-1}, \ln$} & & & & $-0.09 *$ & -0.09 & -0.01 & $-0.12 * *$ & -0.07 & -0.01 & $-0.12 * *$ & -0.07 & -0.01 & $-0.12 * *$ & -0.08 & -0.02 \\
\hline & & & & $(0.05)$ & $(0.07)$ & $(0.02)$ & $(0.05)$ & $(0.06)$ & $(0.02)$ & $(0.05)$ & $(0.06)$ & $(0.02)$ & $(0.05)$ & $(0.07)$ & $(0.02)$ \\
\hline \multirow[t]{2}{*}{$\Delta$ electricity gen ${ }_{\mathrm{s} \text { China t-1, }} \ln$} & & & & & & & -3.98 & $2.58^{*}$ & 2.32 & -3.91 & -0.59 & 1.54 & 0.75 & $1.69 *$ & 1.30 \\
\hline & & & & & & & (8.08) & $(1.32)$ & $(2.97)$ & $(8.03)$ & (2.29) & (2.93) & (5.80) & $(0.98)$ & (2.64) \\
\hline \multirow{2}{*}{$\Delta \mathrm{ST}$ central $_{\text {China t-1 }}, \ln$} & & & & & & & 0.55 & $0.48^{*}$ & 0.44 & 0.71 & 0.13 & 0.06 & & & \\
\hline & & & & & & & $(0.85)$ & $(0.25)$ & $(0.34)$ & $(0.67)$ & $(0.10)$ & $(0.32)$ & & & \\
\hline \multirow[t]{2}{*}{$\Delta \mathrm{ST}$ local ${ }_{\text {China } \mathrm{t}-1}, \ln$} & & & & & & & -0.84 & $0.68^{* * *}$ & $0.75 * * *$ & -0.92 & 0.47 & $0.70^{* * *}$ & & & \\
\hline & & & & & & & $(0.77)$ & $(0.26)$ & $(0.27)$ & $(0.90)$ & $(0.31)$ & $(0.27)$ & & & \\
\hline \multirow[t]{2}{*}{$\Delta$ KnowStock s $_{\text {China t-1 }}, \ln$} & & & & & & & 0.28 & $-0.70^{* *}$ & $-0.53 * *$ & & & & 0.44 & -0.30 & -0.13 \\
\hline & & & & & & & $(0.93)$ & $(0.28)$ & $(0.25)$ & & & & $(0.82)$ & $(0.27)$ & $(0.23)$ \\
\hline \multirow[t]{2}{*}{ constant } & -17.48 & & -3.11 & -23.50 & & 0.66 & -25.05 & & -2.07 & -23.67 & & -0.28 & -24.25 & & -0.26 \\
\hline & $(18.19)$ & & $(2.66)$ & $(19.35)$ & & $(2.70)$ & $(18.34)$ & & $(3.23)$ & $(18.53)$ & & (3.04) & $(17.77)$ & & (3.25) \\
\hline country fixed effects ${ }^{(2)}$ & yes & yes & Mundlak & yes & yes & Mundlak & yes & yes & Mundlak & yes & yes & Mundlak & yes & yes & Mundlak \\
\hline country trend & yes & yes & yes & yes & yes & yes & yes & yes & yes & yes & yes & yes & yes & yes & yes \\
\hline $\mathrm{N}$ & 516 & 516 & 516 & 516 & 516 & 516 & 473 & 473 & 473 & 473 & 473 & 473 & 473 & 473 & 473 \\
\hline r2 & 0.851 & & & 0.859 & & & 0.857 & & & 0.857 & & & 0.857 & & \\
\hline & & 35.50 & 7,952.45 & & 4,229.11 & $7,474.40$ & & $5,701.87$ & $8,167.70$ & & 4,814.84 & $7,815.82$ & & 3,551.34 & 7,738.09 \\
\hline ll & -666.4 & $-755,229$ & $-4,140.9$ & -652.2 & $-632,071$ & $-4,145.7$ & -570.29 & $-526,751$ & $-3,822.9$ & -570.44 & $-550,796$ & $-3,833.8$ & -570.99 & $-559,522$ & $-3,828.1$ \\
\hline
\end{tabular}

Note: $* * * \mathrm{p}<0.01, * * \mathrm{p}<0.05, * \mathrm{p}<0.1$ denote significance level at $1 \%, 5 \%$ and $10 \%$. Cluster robust standard errors in parenthesis. FE Fixed Effects OLS Regression, PPML Poisson Pseudo Maximum Likelihood Regression, NBREG Negative Binominal Regression. (1) Wald $\chi^{2}$ p values not reported, all significant. (2) Mundlak/Chamberlain approach for fixed effects in NBREG model. 
With respect to demand push policies in importing countries, incentive tariffs, implemented to incentivize renewable electricity generation, are estimated to increase solar PV imports from China between 34 percent and 43 percent (Specification 16 and 6). ${ }^{10}$ Other policies such as tax measures and obligations have no statistically significant impact when focusing on NB estimation. Controlling for time trends, the growth of the market for solar PV components in China in terms of solar PV electricity generation has no significant effect. This result however is not surprising as the Chinese market remained very small as outlined above.

The country specific technology transfer and thus foreign knowledge in China, measured as patent-based knowledge stock, has no significant impact on bilateral exports. One reason behind this could be that once technology in terms of patents is transferred to China from one country the product produced with that knowledge or containing this knowledge can be exported to all countries and not just that specific country where the innovation originated. Additionally, national knowledge stock, also based on patent data, remains ambiguous ranging from a negative 0.5 percent significant impact of a one percent change in specification (9) to a non-significant effect in specification (16). With respect to Chinese renewable energy $R \& D$ policy a one percent increase in provincial government $R \& D$ appropriation growth ranges from 0.7 percent (column 13) to 0.75 percent (column 9) and is significant at the one percent level. Central government S\&T appropriation growth on the other hand, showing high but lower growth rates than provincial government $R \& D$ spending, has no significant impact. These results however should be treated with caution for two reasons. First, the true amount of S\&T appropriations allocated to research in solar PV remains unclear and is only approximated in this study. Second, as we have to use growth rates as an explanatory variable and are controlling for time effects at the same time a large amount of explanatory power is lost due to differencing or is captured by controlled time trends.

Table 6 presents results on WETC exports. As export flows are much smaller the number of zero trade flows increases to 37 percent while overdispersion is still present. The sample size is reduced because of all zero outcomes of the dependent variable for

\footnotetext{
${ }^{10}$ Results from calculating e estimated coefficient- 1.
} 
some countries. Negative binominal (NB) estimation in Specification (3), (6), (9), (13) and (16) is still preferred. Results indicate that especially high per capita income countries import WETCs from China - namely, a one percent increase in per capita income increases imports from China between 9.1 percent in the baseline model (Specification 3) to around 7.7 percent in the full model specification (Specification 9,13 and 16). The distance between economic centers of China and the importing country is negative for all specifications indicating a trade decreasing effect for a doubling of distance ranging from 199\% percent to 50 percent. Yet, again as for solar PV exports the coefficient is only significant for specifications not including additional control variables of innovation and R\&D in China. Tariffs on WETC imports from China surprisingly have a positive significant impact on trade flows as a one percent increase in effectively applied tariffs increases trade flows by $0.05 \%$. Thus, this result stays in contrast to the standard belief of liberalization leading to increased trade and might be explained by the small sector analyzed here, the dominance of the international market by only a few companies and the fact that more is exported to emerging markets such as India and Indonesia that apply higher tariffs.

A large market for WETC, approximated by wind electricity generation in importing countries has a negative impact but is only significant at the $5 \%$ level. Namely, a one percent increase in wind electricity generation decreases imports from China by 0.7 percent in Specification (6) to 0.5 percent in Specification (9). This result is surprising as a positive impact was expected. Yet, the existence of a strong wind energy industry in markets with large wind energy electricity generation, such as Denmark, Germany and the US, might explain this finding as demand is rather satisfied by local production. Yet, this finding is in line with the effect renewable energy support policies in importing countries have on trade flows as they are also only weakly significant if at all. Incentive tariffs, for instance, have a statistically weak significant impact increasing trade flows by 55 percent in Specification (6). Yet, the results are insignificant if we additionally control for exporting country characteristics of China using NB estimation in Specification (9), (13) and (16). Chinese market growth for WETC in terms of electricity generation has a significant trade decreasing effect as a one percent increase decreases Chinese exports between 2.1 percent in Specification (9) and 1.3 percent in Specification (16). 
1 Table 6: Preliminary estimation for imports of wind energy technology components from China

\begin{tabular}{|c|c|c|c|c|c|c|c|c|c|c|c|c|c|c|c|}
\hline & \multicolumn{3}{|c|}{ Baseline } & \multicolumn{3}{|c|}{ Market and Policies in $\mathrm{i}$} & \multicolumn{9}{|c|}{ Full Model } \\
\hline & $\begin{array}{l}(1) \\
\text { FE }\end{array}$ & $\begin{array}{c}(2) \\
\text { Poisson }\end{array}$ & $\begin{array}{c}\text { (3) } \\
\text { NBREG }\end{array}$ & $\begin{array}{l}\text { (4) } \\
\text { FE }\end{array}$ & $\begin{array}{c}(5) \\
\text { Poisson }\end{array}$ & $\begin{array}{c}(6) \\
\text { NBREG }\end{array}$ & $\begin{array}{l}\text { (7) } \\
\text { FE }\end{array}$ & $\begin{array}{c}(8) \\
\text { Poisson }\end{array}$ & $\begin{array}{c}\text { (9) } \\
\text { NBREG }\end{array}$ & $\begin{array}{l}\text { (11) } \\
\text { FE }\end{array}$ & $\begin{array}{c}(12) \\
\text { Poisson }\end{array}$ & $\begin{array}{c}\text { (13) } \\
\text { NBREG }\end{array}$ & $\begin{array}{l}\text { (14) } \\
\mathbf{F E}\end{array}$ & $\begin{array}{c}(15) \\
\text { Poisson }\end{array}$ & $\begin{array}{c}(16) \\
\text { NBREG }\end{array}$ \\
\hline $\begin{array}{l}\text { GDP per capita }_{\text {it }}, \ln \\
\text { distance }_{\text {i-china }}, \ln \\
\text { area }_{\mathrm{i}}, \ln \end{array}$ & $\begin{array}{l}8.60^{* * *} \\
(3.12)\end{array}$ & $\begin{array}{l}4.81^{*} \\
(2.75)\end{array}$ & $\begin{array}{l}9.13^{* * *} \\
(1.06) \\
-1.99^{* * *} \\
(0.20) \\
0.81^{* * *} \\
(0.08)\end{array}$ & $\begin{array}{l}8.18^{* * *} \\
(3.12)\end{array}$ & $\begin{array}{l}3.35^{* * * *} \\
(1.03)\end{array}$ & $\begin{array}{l}8.46 * * * \\
(0.97) \\
-0.91 * * * \\
(0.32) \\
0.52 * * * \\
(0.13)\end{array}$ & $\begin{array}{l}10.2^{* * *} \\
(3.79)\end{array}$ & $\begin{array}{l}2.69 \\
(1.88)\end{array}$ & $\begin{array}{l}7.76 * * * \\
(1.37) \\
-0.53 \\
(0.37) \\
0.42 * * * \\
(0.14)\end{array}$ & $\begin{array}{l}10.60 * * * \\
(3.77)\end{array}$ & $\begin{array}{l}2.87 \\
(2.31)\end{array}$ & $\begin{array}{l}7.89 * * * \\
(1.05) \\
-0.51 \\
(0.35) \\
0.41 * * * \\
(0.14)\end{array}$ & $\begin{array}{l}9.78^{* *} \\
(3.87)\end{array}$ & $\begin{array}{l}2.73 \\
(1.68)\end{array}$ & $\begin{array}{l}7.65 * * * \\
(1.36) \\
-0.50 \\
(0.36) \\
0.41 * * * \\
(0.14)\end{array}$ \\
\hline import tariff ${ }_{\text {it china s }}, \ln$ & $\begin{array}{l}-0.02 \\
(0.05)\end{array}$ & $\begin{array}{l}0.04 * \\
(0.02)\end{array}$ & $\begin{array}{l}0.06 * * * \\
(0.01)\end{array}$ & $\begin{array}{l}-0.02 \\
(0.06)\end{array}$ & $\begin{array}{l}0.05^{*} \\
(0.02)\end{array}$ & $\begin{array}{l}0.05 * * * \\
(0.01)\end{array}$ & $\begin{array}{l}-0.02 \\
(0.06)\end{array}$ & $\begin{array}{l}0.05^{* *} \\
(0.02)\end{array}$ & $\begin{array}{l}0.03^{* * * *} \\
(0.01)\end{array}$ & $\begin{array}{l}-0.02 \\
(0.06)\end{array}$ & $\begin{array}{l}0.05^{* *} \\
(0.02)\end{array}$ & $\begin{array}{l}0.03^{* * * *} \\
(0.01)\end{array}$ & $\begin{array}{l}-0.02 \\
(0.06)\end{array}$ & $\begin{array}{l}0.05^{* *} \\
(0.02)\end{array}$ & $\begin{array}{l}0.03 * * * \\
(0.01)\end{array}$ \\
\hline$\Delta$ GDP per capita ${ }_{\text {China }}, \ln$ & $\begin{array}{l}19.22 * * \\
(9.06)\end{array}$ & $\begin{array}{l}-0.86 \\
(4.46)\end{array}$ & $\begin{array}{l}-2.26 \\
(2.05)\end{array}$ & $\begin{array}{l}18.39 * * \\
(8.75)\end{array}$ & $\begin{array}{l}-1.20 \\
(4.12)\end{array}$ & $\begin{array}{l}-1.19 \\
(2.17)\end{array}$ & $\begin{array}{l}23.99 * * \\
(10.35)\end{array}$ & $\begin{array}{l}-4.18 \\
(2.59)\end{array}$ & $\begin{array}{l}7.57 * * \\
(3.14)\end{array}$ & $\begin{array}{l}27.28 * * \\
(10.67)\end{array}$ & $\begin{array}{l}-4.29 \\
(2.71)\end{array}$ & $\begin{array}{l}7.45 * * \\
(3.08)\end{array}$ & $\begin{array}{l}20.19 * \\
(10.56)\end{array}$ & $\begin{array}{l}-3.74 \\
(4.05)\end{array}$ & $\begin{array}{l}6.80^{* *} \\
(2.77)\end{array}$ \\
\hline electricity gen ${ }_{\text {it s }}, \ln$ & & & & $\left(\begin{array}{l}-0.19 \\
(0.84)\end{array}\right.$ & $\begin{array}{l}-0.30 \\
(0.22)\end{array}$ & $\begin{array}{l}-0.72 * * * \\
(0.21)\end{array}$ & $\begin{array}{l}-0.06 \\
(0.76)\end{array}$ & $\begin{array}{l}-0.53^{*} \\
(0.31)\end{array}$ & $\begin{array}{l}-0.54^{* *} \\
(0.25)\end{array}$ & $\begin{array}{l}0.17 \\
(0.77)\end{array}$ & $\begin{array}{l}-0.51^{*} \\
(0.30)\end{array}$ & $\begin{array}{l}-0.52 * * \\
(0.25)\end{array}$ & -0.04 & $\begin{array}{l}-0.53^{*} \\
(0.28)\end{array}$ & $\begin{array}{l}-0.56 * * \\
(0.24)\end{array}$ \\
\hline tax measures it & & & & $\begin{array}{l}-0.56 \\
(0.50)\end{array}$ & $\begin{array}{l}-1.13^{*} \\
(0.60)\end{array}$ & $\begin{array}{l}0.33 \\
(0.30)\end{array}$ & $\begin{array}{l}-0.24 \\
(0.36)\end{array}$ & $\begin{array}{l}-1.07^{* *} \\
(0.47)\end{array}$ & $\begin{array}{l}0.40 \\
(0.34)\end{array}$ & $\begin{array}{l}-0.33 \\
(0.35)\end{array}$ & $\begin{array}{l}-1.11 * * \\
(0.53)\end{array}$ & $\begin{array}{l}0.42 \\
(0.32)\end{array}$ & $\begin{array}{l}-0.28 \\
(0.38)\end{array}$ & $\begin{array}{l}-1.06^{* *} \\
(0.51)\end{array}$ & $\begin{array}{l}0.41 \\
(0.35)\end{array}$ \\
\hline incentive tariffs $_{\text {it }}$ & & & & $\begin{array}{l}0.83 \\
(0.58)\end{array}$ & $\begin{array}{l}0.67 \\
(0.42)\end{array}$ & $\begin{array}{l}0.44^{*} \\
(0.25)\end{array}$ & $\begin{array}{l}0.88 \\
(0.62)\end{array}$ & $\begin{array}{l}0.69 * \\
(0.40)\end{array}$ & $\begin{array}{l}0.42 \\
(0.28)\end{array}$ & $\left(\begin{array}{l}0.87 \\
(0.62)\end{array}\right.$ & $\begin{array}{l}0.70 * \\
(0.42)\end{array}$ & $\begin{array}{l}0.41 \\
(0.28)\end{array}$ & $\begin{array}{l}0.88 \\
(0.62)\end{array}$ & $\begin{array}{l}0.69 * \\
(0.40)\end{array}$ & $\begin{array}{l}0.44 \\
(0.28)\end{array}$ \\
\hline obligations it & & & & $\begin{array}{l}0.40 \\
(0.60)\end{array}$ & $\begin{array}{l}0.05 \\
(0.28)\end{array}$ & $\begin{array}{l}0.37 \\
(0.27)\end{array}$ & $\begin{array}{l}-0.10 \\
(0.57)\end{array}$ & $\begin{array}{l}0.16 \\
(0.28)\end{array}$ & $\begin{array}{l}0.13 \\
(0.31)\end{array}$ & $\begin{array}{l}-0.13 \\
(0.57)\end{array}$ & $\begin{array}{l}0.14 \\
(0.26)\end{array}$ & $\begin{array}{l}0.13 \\
(0.31)\end{array}$ & $\begin{array}{l}-0.09 \\
(0.58)\end{array}$ & $\begin{array}{l}0.16 \\
(0.29)\end{array}$ & $\begin{array}{l}0.13 \\
(0.31)\end{array}$ \\
\hline Tech Transfer ${ }_{\text {i china s } \mathrm{t}-1}, \ln$ & & & & $\left(\begin{array}{l}-0.03 \\
(0.08)\end{array}\right.$ & $\begin{array}{l}0.17^{* * * *} \\
(0.04)\end{array}$ & $\begin{array}{l}0.04 \\
(0.04)\end{array}$ & $\begin{array}{l}0.07 \\
(0.07)\end{array}$ & $\begin{array}{l}0.18^{* * * *} \\
(0.03)\end{array}$ & $\begin{array}{l}0.06 \\
(0.04)\end{array}$ & $\mid \begin{array}{l}0.07 \\
(0.07)\end{array}$ & $\begin{array}{l}0.17 * * * \\
(0.03)\end{array}$ & $\begin{array}{l}0.07 \\
(0.04)\end{array}$ & {$\left[\begin{array}{l}0.08 \\
(0.07)\end{array}\right.$} & $\begin{array}{l}0.18^{* * * *} \\
(0.03)\end{array}$ & $\begin{array}{l}0.06 \\
(0.04)\end{array}$ \\
\hline$\Delta$ electricity gen ${ }_{\text {s China t-1 }} \ln$ & & & & & & & $\begin{array}{l}-4.79 * * * \\
(1.85)\end{array}$ & $\begin{array}{l}0.62 \\
(1.70)\end{array}$ & $\begin{array}{l}-2.09 * * \\
(0.93)\end{array}$ & $\begin{array}{l}-4.16^{* *} \\
(1.80)\end{array}$ & $\begin{array}{l}0.99 \\
(0.90)\end{array}$ & $\begin{array}{l}-1.92 * * * \\
(0.72)\end{array}$ & $\begin{array}{l}-3.01 * * \\
(1.35)\end{array}$ & $\begin{array}{l}0.35 \\
(0.75)\end{array}$ & $\begin{array}{l}-1.26^{* * *} \\
(0.43)\end{array}$ \\
\hline$\Delta \mathrm{ST}$ central $_{\text {China t-1 }}, \ln$ & & & & & & & $\begin{array}{l}0.62 \\
(0.84)\end{array}$ & $\begin{array}{l}-0.09 \\
(0.55)\end{array}$ & $\begin{array}{l}0.48 \\
(0.45)\end{array}$ & $\left(\begin{array}{l}0.31 \\
(0.83)\end{array}\right.$ & $\begin{array}{l}-0.17 \\
(0.43)\end{array}$ & $\begin{array}{l}0.44 \\
(0.43)\end{array}$ & & & \\
\hline$\Delta$ ST local $_{\text {China }}-1$, ln & & & & & & & $\begin{array}{l}2.58 \\
(1.85)\end{array}$ & $\begin{array}{l}-0.32 \\
(1.63)\end{array}$ & $\begin{array}{l}0.87 \\
(1.05)\end{array}$ & $\begin{array}{l}2.60 \\
(1.85)\end{array}$ & $\begin{array}{l}-0.66 \\
(0.90)\end{array}$ & $\begin{array}{l}0.69 \\
(0.83)\end{array}$ & & & \\
\hline$\Delta$ KnowStock s China t-1, $\ln$ & & & & & & & $\begin{array}{l}1.96^{*} \\
(1.11)\end{array}$ & $\begin{array}{l}0.62 \\
(1.58)\end{array}$ & $\begin{array}{l}0.23 \\
(0.90)\end{array}$ & & & & $\begin{array}{l}1.75 \\
(1.09)\end{array}$ & $\begin{array}{l}0.75 \\
(0.94)\end{array}$ & $\begin{array}{l}-0.31 \\
(0.73)\end{array}$ \\
\hline constant & $\begin{array}{l}-82.9 * * * \\
(29.98)\end{array}$ & & $\begin{array}{l}4.90 \\
(3.13) \\
\end{array}$ & $\begin{array}{l}-79.1^{* * *} \\
(30.12)\end{array}$ & & $-2,706.67$ & {$\left[\begin{array}{l}-98.7 * * * \\
(36.79)\end{array}\right.$} & & $\begin{array}{l}18.48^{* * *} \\
(4.66)\end{array}$ & $\begin{array}{l}-103^{* * * *} \\
(36.58)\end{array}$ & & $\begin{array}{l}18.95 * * * \\
(4.21)\end{array}$ & $\begin{array}{l}-94.16 * * \\
(37.59)\end{array}$ & & $\begin{array}{l}18.80^{* * * *} \\
(4.65)\end{array}$ \\
\hline $\begin{array}{l}\text { country fixed effects } \\
\text { country trend }\end{array}$ & $\begin{array}{l}\text { yes } \\
\text { yes }\end{array}$ & $\begin{array}{l}\text { yes } \\
\text { yes }\end{array}$ & $\begin{array}{l}\text { Mundlak } \\
\text { yes }\end{array}$ & $\begin{array}{l}\text { yes } \\
\text { yes }\end{array}$ & $\begin{array}{l}\text { yes } \\
\text { yes }\end{array}$ & $\begin{array}{l}\text { Mundlak } \\
\text { yes }\end{array}$ & \begin{tabular}{|l} 
yes \\
yes
\end{tabular} & $\begin{array}{l}\text { yes } \\
\text { yes }\end{array}$ & $\begin{array}{l}\text { Mundlak } \\
\text { yes }\end{array}$ & \begin{tabular}{|l} 
yes \\
yes
\end{tabular} & $\begin{array}{l}\text { yes } \\
\text { yes }\end{array}$ & $\begin{array}{l}\text { Mundlak } \\
\text { yes }\end{array}$ & $\begin{array}{l}\text { yes } \\
\text { yes }\end{array}$ & $\begin{array}{l}\text { yes } \\
\text { yes }\end{array}$ & $\begin{array}{l}\text { Mundlak } \\
\text { yes }\end{array}$ \\
\hline $\begin{array}{l}\mathrm{N} \\
\mathrm{r} 2\end{array}$ & $\begin{array}{l}516 \\
0.742\end{array}$ & 492 & 492 & $\begin{array}{l}516 \\
0.747\end{array}$ & 492 & 492 & $\begin{array}{l}473 \\
0.760\end{array}$ & 451 & 451 & $\begin{array}{l}473 \\
0.758\end{array}$ & 451 & 451 & $\begin{array}{l}473 \\
0.757\end{array}$ & 451 & 451 \\
\hline $\begin{array}{l}\text { Wald chi2 } \\
\text { ll }\end{array}$ & -894.61 & $\begin{array}{l}800.73 \\
-200,893\end{array}$ & $\begin{array}{l}2,608.43 \\
-2,713\end{array}$ & -890.13 & $\begin{array}{l}295 \text { Mio. } \\
-166,694\end{array}$ & $\begin{array}{l}2492.54 \\
-2706.67\end{array}$ & -782.99 & $\begin{array}{l}2,617.64 \\
-158,310\end{array}$ & $\begin{array}{l}2,639.07 \\
-2,545.09\end{array}$ & -784.78 & $\begin{array}{l}2,420.90 \\
-158,699\end{array}$ & $\begin{array}{l}2,648.36 \\
-2,545.13\end{array}$ & -785.24 & $\begin{array}{l}1,804.07 \\
-158,398\end{array}$ & $\begin{array}{l}2,631.53 \\
-2,545.79\end{array}$ \\
\hline
\end{tabular}

Note: *** $\mathrm{p}<0.01, * * \mathrm{p}<0.05, * \mathrm{p}<0.1$ denote significance level at $1 \%, 5 \%$ and $10 \%$. Cluster robust standard errors in parenthesis. FE Fixed Effects OLS Regression, PPML Poisson Pseudo Maximum Likelihood Regression, NBREG Negative Binominal Regression. (1) Wald $\chi^{2}$ p values not reported, all significant. (2) Mundlak/Chamberlain approach for fixed effects in NBREG model. 
This result highlights that increasing national demand might be satisfied with Chinese production that potentially reduces exports. Thus, it is in line with the finding for the market size variable in importing countries.

Country specific technology transfer and national knowledge stock on wind energy technology - similar to the solar PV result in Table 5- have no significant impact on trade flows in a NB estimation framework. Differently, to the results in Table $5-R \& D$ appropriations of both central and provincial governments have no significant effect on exports.

\section{$7 \quad$ Discussion and Conclusion}

The export performance of China with respect to solar PV and wind energy technology components (WETC) has been exceptional since 2005. Our research aimed at outlining this development and examining the drivers behind it. We show that China runs large exports surpluses with only a few developed countries in both technology sectors and that it gained a considerable comparative advantage. Our findings are in line with more general trade studies outlining that China has developed comparative advantages in highly sophisticated good exports that do not necessarily corresponding to its level of development (Rodrik, 2006 Schott, 2008). We show that China trades only marginally with other emerging markets and developing countries - especially with respect to solar PV technology components.

This empirical study is the first attempt at estimating the driving factors of Chinese solar PV and wind energy components exports. The few existing studies in this field are limited to descriptive studies trade development and policy performance and innovation. We conduct an ex-post econometric study using an augmented gravity model and a panel dataset of 43 countries from the developed and developing world that imported solar PV and WETCs from China between 1996 and 2008. In addition to controlling for standard socioeconomic variables derived from the gravity trade literature, we consider several explanatory factors accounting for market, policy and innovation effects steaming from both importing countries and China. Specifically, we are interested in the effect of renewable energy support schemes and the renewable energy market size in importing countries on export flows from China. Furthermore, the role of Chinese R\&D policy, 
innovation and bilateral technology transfer as well as the Chinese demand market for solar PV and WETCs is of interest.

The results highlight that importing country per capita income has a significant positive effect on solar PV and WETC imports from China. The growth of Chinese per capita income also has a significant effect on exports. This is in line with the general trade literature showing that trade increases with country income. It also supports the environmental Kuznets curve hypothesis arguing that demand for (and supply of) environmental goods increases with income. Additionally, the area of importing countries, seen as a proxy for economic mass and also for renewable energy potential, has a significant effect.

With respect to trade costs we find that distance has no significant effect but that high import tariffs have a negative effect on solar PV imports, as higher costs are associated. This result is insightful from the perspective that reduced tariffs are likely to increase the availability of this technology in the global market, in particular for developing countries. Results on tariffs applied to WETC imports, however, are surprising as higher tariffs are associated with higher imports. However, this can be explained by several factors. First, WETC exports from China are extremely small compared to exports of solar PV components. Second, a larger share of exports is imported by developing countries, especially the East Asian economies and India, which apply higher tariffs. Thus, the result might be driven by the small size of the sector analyzed.

The results also highlight that market size in importing countries is very important for understanding trade flows of solar PV components but not decisive for determining WETC exports. Strong development of electricity generation as an indicator for market size increases imports of components to satisfy demand. The results for wind energy technologies are different as a large market in terms of electricity generation in importing countries reduces imports of wind energy components. A possible explanation for this finding is that countries with a large amount of generation, such as the USA, Denmark and Germany, have a strong, competitive wind turbine industry themselves and are thus not as reliant on technology imports. Additionally, countries with a smaller market, such as India and Indonesia import relatively more - compared to the solar PV market analysis. Growth of the wind energy market in terms of electricity generation in China has a 
negative impact on respective exports, while that of solar PV did not. This is in contrast to Sawhney and Kahn (2012) who suggest that solar PV exports to the US are determined by the exporting country market size. However, the descriptive analysis also highlighted while the national market remained small in terms of solar PV electricity generation, the solar PV component industry became particularly successful in targeting foreign markets. On the contrary, while the country developed a large home market for electricity generated from wind energy, its export performance in the sector increased but remained relatively small. In terms of policy this is interesting as it suggests that a future growth of the home market for solar PV in China might eventually decrease the currently large export surplus of the sector as rather the home market will be supplied. However, more research is required in this respect.

We also show that the policy structure supporting renewable energy dissemination in importing countries has some effect at least on solar PV component imports from China. Differentiating between incentive tariffs, obligations and tax measures, we find that countries with an incentive tariff scheme in place are importing significantly more solar PV components than countries that have only implemented tax measures and obligations. This makes sense insofar as feed-in tariffs are considered to be a very effective policy instrument for increasing generation from solar PV. However, these results should be interpreted cautiously for several reasons. First, we only test the effect of policy existence, as available data does not allow controlling for policy strength and policy design across countries. Second, numerous countries have simultaneously implemented policy designed to strengthen renewable energy dissemination, but we only test for selected policies neglecting this policy mix.

The paper also aims at identifying the effect of the Chinese R\&D policy and innovation as well as the role of foreign knowledge as potential drivers for exports. Results are ambiguous but not in contrast to findings in the literature. We use data on central and provincial government S\&T appropriations that have been identified in earlier literature as being directed to $R \& D$ on renewable energy.

We find that only provincial R\&D spending growth has a positive effect on Chinese solar PV exports, while central government R\&D spending seems to have no empirically significant effect. We see several reasons for this finding. First, provincial government 
R\&D spending experienced greater growth rates than that from the central government. Second, while central government S\&T appropriations for renewable energies are linked to public institutions and universities, and thus the provision of public goods or basic research, this link is not so clear for provincial government appropriations, which are likely to be directed to specific technologies and projects. Also, indirectly explaining the insignificance of central government $R \& D$ appropriation, investment support for manufacturing through, among other, R\&D policies has not been sufficiently tied to innovation incentives (Grau et al., 2012). However, these results however should be treated cautiously for two reasons. First, the true amount of S\&T appropriations allocated to research in solar PV and wind energy remains unclear and is only approximated in this study. Second, as we have to use growth rates as an explanatory variable and are controlling for time effects a large amount of explanatory power can be lost due to differencing or is captured by controlled time trends.

We use technology specific patent data to obtain national and foreign knowledge stock in China in order to test the role of innovation and technology transfer in the context of trade. We show that the national knowledge stock on wind and solar PV technologies increased substantially in China. Estimation results however are puzzling. Growth in national knowledge does not play a significant role in determining exports of either technology components. Descriptively we highlighted that countries that have transferred more innovations to China in terms of patents on solar PV and wind energy technology also import more of the respective technology components. Yet, empirically we do not find any effect of bilateral knowledge transfer to China on technology component imports from China. One reason behind this could be that once technology, in terms of patents, is transferred to China from one country, the product produced with that knowledge or containing this knowledge can be exported to all countries and not just the specific country where the innovation originated. Furthermore, several data limitations and a reflection of the existing literature on innovation and the clean energy sector in China potentially help explain these results and require further research. The estimation techniques adopted in this study do not allow measuring different means of technology transfer, such as purchasing manufacturing equipment or hiring a skilled foreign trained workforce, as outlined by de la Tour (2011). Also, the literature suggests 
that both industries moved from imitation and cooperation to indigenous innovation (Lewis, 2011). Yet, imitation is not likely to be patented. Furthermore, own knowledge generation only recently became more important ( $\underline{\mathrm{Wu} \text { and Mathews, 2012) }}$ and thus might not yet be reflected in the period analyzed. Additionally, the patent data used in this context does not control for innovations in the technology used for production of components used for electricity generation but only differentiate the latter. Further, although traded products are uniquely identified in international trade statistics, thus permitting a sector specific analysis, the product position in the production chain cannot be identified. However, knowledge transfer and innovation in production technologies and understanding whether upstream or final products are produced and traded might also be central in explaining Chinese industry development. 


\section{Appendix}

Appendix 1: Nomenclature of solar photovoltaic and wind energy components in, HS 1996

\begin{tabular}{|c|c|}
\hline HS Code $\quad$ E & \\
\hline \multicolumn{2}{|c|}{ Solar Photovoltaic (PV) components } \\
\hline 850440 & $\begin{array}{l}\text { Static converters [Inverters for converting DC power to AC power] } \\
\text { change solar energy into electricity. }\end{array}$ \\
\hline 850720 & $\begin{array}{l}\text { Other lead-acid accumulators [solar batteries], i.e batteries for } \\
\text { energy storage in off-grid photovoltaic systems. }\end{array}$ \\
\hline 854140 & $\begin{array}{l}\text { Photosensitive semiconductor devices, including photovoltaic cells } \\
\text { whether or not assembled in modules or made up into panels; light } \\
\text { emitting diodes. }\end{array}$ \\
\hline \multicolumn{2}{|c|}{ Wind energy components } \\
\hline 841280 & Other [Steam engines, windmill, without pumps \\
\hline 841290 & Parts for Steam engines and windmills.] \\
\hline 841381 & $\begin{array}{l}\text { Pumps for liquids, whether or not fitted with a measuring device, } \\
\text { other pumps }\end{array}$ \\
\hline 850231 & Generating sets, electric, wind-powered \\
\hline 850239 & Other generating sets \\
\hline 850240 & $\begin{array}{l}\text { Electric generating set and rotary converters [set combining an } \\
\text { electric generator and either a hydraulic turbine or a sterling } \\
\text { engine] }\end{array}$ \\
\hline 730820 & Wind Turbine Towers \\
\hline
\end{tabular}

Sources: OECD, Eurostat (1999); Steenblik, R. $(2005,2006)$ Wind, I. (2008). 
Appendix 2: Development of Chinese exports and imports of components for potential renewable energy use and export and import market shares compared to selected countries

\begin{tabular}{|c|c|c|c|c|c|c|c|c|c|c|}
\hline & \multicolumn{5}{|c|}{ Solar Photovoltaik } & \multicolumn{5}{|c|}{ Wind } \\
\hline & 1996 & 2000 & 2004 & 2008 & 2010 & 1996 & 2000 & 2004 & 2008 & 2010 \\
\hline \multicolumn{11}{|c|}{ 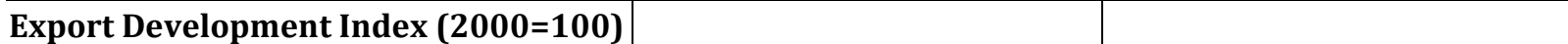 } \\
\hline Germany & 81 & 100 & 163 & 586 & 717 & 123 & 100 & 208 & 997 & 901 \\
\hline China & 39 & 100 & 277 & 1587 & 2681 & 48 & 100 & 356 & 1774 & 1216 \\
\hline Denmark & 84 & 100 & 114 & 239 & 380 & 87 & 100 & 228 & 627 & 575 \\
\hline Japan & 59 & 100 & 155 & 247 & 253 & 59 & 100 & 135 & 394 & 225 \\
\hline Korea, Rep. & 128 & 100 & 206 & 461 & 0 & 98 & 100 & 181 & 364 & 0 \\
\hline Spain & 59 & 100 & 396 & 511 & 1931 & 56 & 100 & 147 & 572 & 995 \\
\hline United Kingdom & 68 & 100 & 92 & 178 & 142 & 129 & 100 & 95 & 176 & 132 \\
\hline United States & 54 & 100 & 84 & 151 & 163 & 129 & 100 & 187 & 386 & 583 \\
\hline \multicolumn{11}{|c|}{ Import Development Index $(2000=100)$} \\
\hline Germany & 71 & 100 & 207 & 619 & 1073 & 58 & 100 & 273 & 415 & 530 \\
\hline China & 23 & 100 & 403 & 810 & 1254 & 102 & 100 & 258 & 323 & 278 \\
\hline Denmark & 89 & 100 & 117 & 256 & 216 & 167 & 100 & 164 & 558 & 497 \\
\hline Japan & 60 & 100 & 130 & 177 & 204 & 37 & 100 & 222 & 355 & 253 \\
\hline Korea, Rep. & 54 & 100 & 224 & 557 & 0 & 94 & 100 & 186 & 347 & 0 \\
\hline Spain & 69 & 100 & 187 & 3693 & 1005 & 133 & 100 & 134 & 443 & 222 \\
\hline United Kingdom & 61 & 100 & 78 & 137 & 126 & 114 & 100 & 149 & 466 & 827 \\
\hline United States & 53 & 100 & 91 & 153 & 181 & 44 & 100 & 115 & 821 & 475 \\
\hline \multicolumn{11}{|c|}{ Global export share in percent } \\
\hline Germany & 15.9 & 11.2 & 13.4 & 17.1 & 15.9 & 10.2 & 7.5 & 9.5 & 15.8 & 16.1 \\
\hline China & 5.0 & 7.4 & 15.0 & 30.6 & 39.1 & 1.1 & 2.0 & 4.4 & 7.7 & 5.9 \\
\hline Denmark & 1.9 & 1.3 & 1.1 & 0.8 & 1.0 & 10.3 & 10.8 & 15.0 & 14.3 & 14.8 \\
\hline Japan & 15.8 & 15.3 & 17.5 & 9.9 & 7.7 & 3.5 & 5.3 & 4.4 & 4.5 & 2.9 \\
\hline Korea, Rep. & 3.2 & 1.4 & 2.2 & 1.7 & 0.0 & 0.7 & 0.7 & 0.7 & 0.5 & 0.0 \\
\hline Spain & 0.7 & 0.6 & 1.8 & 0.8 & 2.4 & 2.1 & 3.4 & 3.1 & 4.2 & 8.2 \\
\hline United Kingdom & 8.0 & 6.8 & 4.6 & 3.2 & 1.9 & 7.8 & 5.4 & 3.2 & 2.0 & 1.7 \\
\hline United States & 14.9 & 15.9 & 9.9 & 6.3 & 5.2 & 18.5 & 12.9 & 14.8 & 10.6 & 18.1 \\
\hline \multicolumn{11}{|c|}{ Global import share in percent } \\
\hline Germany & 11.2 & 8.4 & 12.9 & 15.5 & 20.7 & 8.0 & 8.7 & 15.2 & 7.8 & 11.4 \\
\hline China & 1.4 & 3.2 & 9.6 & 7.8 & 9.3 & 8.3 & 5.1 & 8.5 & 3.6 & 3.5 \\
\hline Denmark & 0.9 & 0.6 & 0.5 & 0.4 & 0.3 & 1.9 & 0.7 & 0.8 & 0.9 & 0.9 \\
\hline France & 5.6 & 4.7 & 3.5 & 3.4 & 4.8 & 9.4 & 5.5 & 3.0 & 2.3 & 2.5 \\
\hline Italy & 3.7 & 2.8 & 2.8 & 4.3 & 13.9 & 3.1 & 2.4 & 2.1 & 2.5 & 2.4 \\
\hline Japan & 9.6 & 8.5 & 8.1 & 4.5 & 4.0 & 1.2 & 2.0 & 2.9 & 1.6 & 1.3 \\
\hline Korea, Rep. & 3.0 & 2.9 & 4.8 & 4.8 & 0.0 & 4.4 & 3.0 & 3.6 & 2.2 & 0.0 \\
\hline Netherlands & 2.5 & 3.7 & 3.7 & 2.3 & 3.8 & 2.0 & 1.7 & 1.9 & 1.7 & 1.6 \\
\hline Spain & 1.5 & 1.1 & 1.6 & 12.6 & 2.6 & 5.7 & 2.7 & 2.3 & 2.6 & 1.5 \\
\hline United Kingdom & 7.4 & 6.4 & 3.7 & 2.6 & 1.9 & 6.9 & 3.8 & 3.6 & 3.8 & 7.7 \\
\hline United States & 30.5 & 30.5 & 20.3 & 13.8 & 12.7 & 9.9 & 14.0 & 10.4 & 25.0 & 16.6 \\
\hline
\end{tabular}


Appendix 3: Trade related sector specific indicators of competitiveness of China and selected countries by components for potential renewable energy use

\begin{tabular}{|c|c|c|c|c|c|c|c|c|c|c|}
\hline & \multicolumn{5}{|c|}{ Solar Photovoltaik } & \multicolumn{5}{|c|}{ Wind } \\
\hline & \multicolumn{5}{|c|}{19962000200420082010} & \multicolumn{5}{|c|}{19962000200420082010} \\
\hline \multicolumn{6}{|c|}{ Relative World Market Share (RWS) ${ }^{(1)}$} & & & & & \\
\hline Germany & 1.2 & 1.1 & 1.1 & 1.5 & 1.4 & 0.8 & 0.7 & 0.8 & 1.4 & 1.4 \\
\hline China & 1.5 & 1.8 & 2.1 & 3.0 & 2.9 & 0.3 & 0.5 & 0.6 & 0.7 & 0.4 \\
\hline Denmark & 1.8 & 1.6 & 1.3 & 1.0 & 1.3 & 9.9 & 13.3 & 17.7 & 18.6 & 19.9 \\
\hline Japan & 1.5 & 1.8 & 2.5 & 1.7 & 1.2 & 0.3 & 0.6 & 0.6 & 0.8 & 0.4 \\
\hline Korea, Rep. & 0.9 & 0.4 & 0.7 & 0.5 & & 0.2 & 0.2 & 0.2 & 0.2 & \\
\hline Spain & 0.2 & 0.3 & 0.8 & 0.4 & 1.1 & 0.8 & 1.6 & 1.3 & 2.0 & 3.9 \\
\hline United & & & & & & & & & & \\
\hline Kingdom & 1.2 & 1.2 & 1.0 & 0.9 & 0.5 & 1.2 & 1.0 & 0.7 & 0.6 & 0.5 \\
\hline United & & & & & & & & & & \\
\hline States & 1.0 & 1.2 & 1.1 & 0.7 & 0.6 & 1.3 & 1.0 & 1.6 & 1.2 & 2.0 \\
\hline \multicolumn{11}{|c|}{ Relative Trade Position (RTP) (2) } \\
\hline Germany & 0.1 & 0.0 & -0.1 & 0.0 & -0.2 & 0.1 & -0.2 & -0.3 & 0.2 & 0.0 \\
\hline China & 0.5 & 0.3 & 0.1 & 0.6 & 0.6 & -0.8 & -0.5 & -0.4 & 0.2 & 0.1 \\
\hline Denmark & 0.3 & 0.3 & 0.3 & 0.3 & 0.5 & 0.7 & 0.8 & 0.9 & 0.9 & 0.9 \\
\hline Japan & 0.2 & 0.2 & 0.3 & 0.3 & 0.3 & 0.5 & 0.3 & 0.1 & 0.4 & 0.3 \\
\hline Korea, Rep. & 0.0 & -0.4 & -0.5 & -0.5 & & -0.7 & -0.7 & -0.7 & -0.7 & \\
\hline Spain & -0.4 & -0.4 & 0.0 & -0.9 & -0.1 & -0.4 & 0.0 & 0.0 & 0.1 & 0.6 \\
\hline United & & & & & & & & & & \\
\hline Kingdom & 0.0 & -0.1 & 0.0 & 0.1 & 0.0 & 0.1 & 0.0 & -0.2 & -0.4 & -0.7 \\
\hline United & & & & & & & & & & \\
\hline States & -0.4 & -0.4 & -0.4 & -0.4 & -0.4 & 0.3 & -0.2 & 0.1 & -0.5 & -0.1 \\
\hline \multicolumn{11}{|c|}{ Revealed Comparaitve Advantage (RCA) (3) } \\
\hline Germany & 1.0 & 0.9 & 0.6 & 0.8 & 0.6 & 1.1 & 0.5 & 0.4 & 1.2 & 0.9 \\
\hline China & 3.0 & 1.7 & 1.1 & 2.5 & 3.2 & 0.1 & 0.3 & 0.4 & 1.1 & 1.0 \\
\hline Denmark & 1.8 & 2.0 & 1.9 & 1.9 & 3.4 & 6.0 & 11.8 & 16.1 & 13.8 & 13.2 \\
\hline Japan & 1.1 & 1.1 & 1.3 & 1.7 & 1.5 & 2.4 & 1.4 & 0.9 & 1.8 & 1.4 \\
\hline Korea, Rep. & 1.1 & 0.3 & 0.3 & 0.3 & & 0.2 & 0.1 & 0.1 & 0.2 & \\
\hline Spain & 0.5 & 0.7 & 1.5 & 0.1 & 1.2 & 0.5 & 1.4 & 1.6 & 2.0 & 5.8 \\
\hline United & & & & & & & & & & \\
\hline Kingdom & 1.1 & 1.0 & 1.3 & 1.6 & 1.3 & 1.3 & 1.2 & 0.9 & 0.6 & 0.2 \\
\hline United & & & & & & & & & & \\
\hline States & 0.7 & 0.8 & 0.9 & 0.8 & 0.8 & 3.0 & 1.2 & 2.5 & 0.6 & 1.7 \\
\hline
\end{tabular}

Sources: Authors calculations based on UNCTAD Comtrade (2012)

Notes: (1) A RWS value $>1$ indicates that exports of a country in a specific product group account for a larger share of total exports of that country compared to the global average.

(2) A RTP value $>0$ indicates that national industries are better in targeting foreign markets than foreign industries are in targeting the national market.

(3) A RCA value $>1$ indicates a comparative advantage of a country in the specific product group in terms of trade. 
Appendix 4: Share of region and selected countries on Chinese exports and imports of potential renewable energy components (in percent)

\begin{tabular}{|c|c|c|c|c|c|c|c|c|c|c|c|c|c|c|c|c|}
\hline & \multicolumn{8}{|c|}{ Photovoltaic } & \multicolumn{8}{|c|}{ Wind } \\
\hline & \multicolumn{4}{|c|}{ Export } & \multicolumn{4}{|c|}{ Import } & \multicolumn{4}{|c|}{ Export } & \multicolumn{4}{|c|}{ Import } \\
\hline & 1996 & 62004 & 42008 & 82010 & 01996 & 62004 & 42008 & 82010 & 1996 & 62004 & 42008 & 82010 & 01996 & 62004 & 42008 & 82010 \\
\hline East Asian \& Pacific & 5.5 & 6.8 & 3.1 & 2.5 & 4.2 & 10.5 & 15.3 & 20.4 & 44.1 & 13.2 & 10.3 & 15.9 & 0.2 & 0.2 & 0.1 & 0.2 \\
\hline Malaysia & 4.1 & 2.2 & 1.1 & 0.8 & 1.4 & 3.3 & 5.5 & 10.0 & 10.2 & 1.0 & 0.6 & 1.3 & 0.2 & 0.1 & 0.1 & 0.1 \\
\hline Thailand & 0.3 & 1.3 & 0.6 & 0.4 & 1.8 & 3.9 & 5.1 & 3.9 & 12.4 & 3.7 & 0.9 & 1.3 & 0.0 & 0.1 & 0.0 & 0.0 \\
\hline Vietnam & 0.1 & 0.2 & 0.4 & 0.4 & 0.0 & 0.0 & 0.2 & 0.4 & 3.6 & 1.0 & 2.8 & 4.3 & 0.0 & 0.0 & 0.0 & 0.0 \\
\hline Indonesia & 0.2 & 0.6 & 0.5 & 0.4 & 0.2 & 1.8 & 1.8 & 2.0 & 4.9 & 5.7 & 3.9 & 4.8 & 0.0 & 0.0 & 0.0 & 0.0 \\
\hline Philippines & 0.7 & 2.2 & 0.4 & 0.3 & 0.9 & 1.5 & 2.8 & 4.0 & 10.8 & 1.2 & 1.1 & 1.1 & 0.0 & 0.0 & 0.0 & 0.0 \\
\hline Eastern Europe & 0.2 & 1.2 & 1.4 & 1.1 & 0.2 & 0.1 & 0.4 & 0.1 & 0.1 & 2.5 & 4.0 & 3.6 & 1.1 & 0.2 & 0.1 & 0.9 \\
\hline Russia & 0.1 & 0.8 & 0.8 & 0.5 & 0.2 & 0.0 & 0.0 & 0.0 & 0.0 & 0.3 & 0.8 & 0.7 & 1.0 & 0.1 & 0.0 & 0.0 \\
\hline Ukraine & 0.0 & 0.2 & 0.2 & 0.3 & 0.0 & 0.0 & 0.0 & 0.0 & 0.0 & 0.1 & 0.4 & 0.2 & 0.0 & 0.0 & 0.1 & 0.7 \\
\hline Latin America & 0.5 & 1.6 & 1.9 & 1.7 & 0.0 & 0.1 & 0.2 & 0.1 & 2.7 & 3.8 & 3.6 & 3.0 & 0.0 & 0.3 & 0.0 & 0.0 \\
\hline Brazil & 0.3 & 0.9 & 1.1 & 1.0 & 0.0 & 0.0 & 0.0 & 0.0 & 0.1 & 0.4 & 0.5 & 0.9 & 0.0 & 0.3 & 0.0 & 0.0 \\
\hline Mexico & 0.7 & 1.8 & 1.4 & 0.9 & 0.0 & 0.8 & 0.7 & 0.4 & 0.0 & 0.8 & 0.3 & 0.3 & 0.8 & 0.1 & 0.0 & 0.0 \\
\hline Argentina & 0.1 & 0.1 & 0.1 & 0.1 & 0.0 & 0.0 & 0.0 & 0.0 & 1.6 & 0.5 & 0.1 & 0.3 & 0.0 & 0.0 & 0.0 & 0.0 \\
\hline South Asia & 0.2 & 1.7 & 3.3 & 2.2 & 0.0 & 0.5 & 0.5 & 1.0 & 4.3 & 3.7 & 16.8 & 11.4 & 0.0 & 0.0 & 0.2 & 0.4 \\
\hline India & 0.0 & 1.4 & 2.8 & 1.7 & 0.0 & 0.5 & 0.5 & 1.0 & 0.8 & 0.6 & 14.3 & 8.6 & 0.0 & 0.0 & 0.2 & 0.4 \\
\hline OECD & 93.0 & 86.7 & 87.9 & 90.5 & 95.5 & 88.7 & 83.5 & 78.4 & 32.8 & 61.9 & 49.4 & 50.5 & 98.6 & 99.3 & 99.5 & 98.5 \\
\hline Germany & 4.9 & 11.5 & 19.2 & 25.0 & 5.3 & 6.3 & 15.3 & 17.1 & 0.9 & 3.8 & 1.9 & 2.6 & 10.7 & 14.1 & 18.8 & 14.5 \\
\hline Italy & 1.8 & 1.8 & 4.6 & 15.5 & 1.0 & 0.8 & 1.6 & 1.2 & 0.2 & 2.1 & 1.6 & 1.3 & 2.8 & 2.8 & 7.6 & 4.5 \\
\hline Netherlands & 1.4 & 4.3 & 4.4 & 12.9 & 0.2 & 0.2 & 0.4 & 0.3 & 0.0 & 0.7 & 0.5 & 1.1 & 1.1 & 1.3 & 1.5 & 1.2 \\
\hline United States & 42.3 & 25.6 & 12.1 & 11.2 & 11.8 & 6.7 & 7.3 & 5.6 & 3.8 & 23.5 & 21.8 & 19.2 & 22.3 & 10.1 & 11.2 & 15.9 \\
\hline Japan & 24.3 & 20.8 & 7.1 & 4.1 & 61.4 & 58.7 & 37.6 & 32.3 & |18.2 & 14.3 & 11.3 & 11.2 & 14.3 & 11.1 & 29.7 & 34.6 \\
\hline Australia & 1.0 & 0.8 & 0.8 & 3.0 & 0.1 & 0.3 & 1.0 & 0.0 & 1.2 & 1.7 & 1.3 & 3.8 & 1.0 & 0.3 & 0.1 & 0.3 \\
\hline Korea, Rep. & 1.4 & 6.5 & 5.9 & 2.8 & 7.4 & 6.6 & 8.1 & 11.0 & 2.3 & 3.3 & 2.6 & 2.6 & 2.9 & 1.7 & 2.4 & 3.7 \\
\hline France & 3.9 & 2.4 & 1.9 & 2.6 & 1.6 & 2.4 & 1.1 & 2.4 & 1.3 & 1.1 & 0.5 & 0.5 & 3.5 & 36.9 & 1.6 & 5.5 \\
\hline Spain & 0.6 & 0.5 & 21.7 & 2.1 & 0.1 & 0.4 & 0.3 & 0.1 & 0.0 & 0.7 & 0.9 & 0.4 & 24.2 & 4.3 & 8.2 & 5.6 \\
\hline Canada & 0.7 & 1.2 & 0.4 & 0.8 & 1.2 & 0.4 & 0.5 & 0.3 & 1.7 & 2.5 & 1.3 & 0.9 & 0.7 & 0.1 & 0.3 & 0.1 \\
\hline United Kingdom & 7.5 & 2.8 & 0.9 & 0.8 & 2.8 & 0.9 & 0.8 & 0.7 & 2.2 & 1.0 & 0.6 & 1.0 & 6.6 & 2.2 & 2.0 & 1.9 \\
\hline Turkey & 0.1 & 0.9 & 0.6 & 0.5 & 0.0 & 0.0 & 0.0 & 0.0 & 0.4 & 2.3 & 1.7 & 2.7 & 0.0 & 0.0 & 0.0 & 0.1 \\
\hline Sweden & 0.2 & 0.4 & 0.4 & 0.3 & 0.8 & 0.9 & 1.3 & 0.6 & 0.0 & 0.1 & 0.2 & 0.6 & 0.7 & 0.9 & 1.5 & 2.0 \\
\hline Denmark & 0.0 & 0.1 & 0.1 & 0.2 & 0.3 & 0.5 & 0.7 & 0.5 & 0.0 & 0.3 & 0.9 & 0.3 & 3.4 & 6.8 & 7.5 & 2.0 \\
\hline Austria & 0.2 & 0.2 & 0.1 & 0.1 & 0.0 & 0.2 & 0.8 & 0.7 & 0.0 & 0.0 & 0.1 & 0.3 & 0.7 & 0.4 & 1.0 & 0.5 \\
\hline Africa \& Middle East & 0.5 & 1.9 & 2.3 & 1.8 & 0.0 & 0.0 & 0.1 & 0.1 & 9.4 & 13.6 & 11.9 & 13.1 & 0.0 & 0.1 & 0.0 & 0.0 \\
\hline South Africa & 0.1 & 0.4 & 0.4 & 0.4 & 0.0 & 0.0 & 0.0 & 0.0 & 0.1 & 0.7 & 1.1 & 0.6 & 0.0 & 0.1 & 0.0 & 0.0 \\
\hline Iran & 0.1 & 0.2 & 0.3 & 0.2 & 0.0 & 0.0 & 0.0 & 0.0 & 7.4 & 1.6 & 0.2 & 1.4 & 0.0 & 0.0 & 0.0 & 0.0 \\
\hline
\end{tabular}


Appendix 5: Patents as innovation and technology transfer indicator - methodology

Innovation can be measured using different indicators such as $R \& D$ expenditure, number of researcher (input measure of the inventive process) and patents (output measure of inventive process). Different means of technology transfer are identified and used in the literature. The most common are licensing, foreign direct investment (FDI), international trade and movement of personnel. Yet, cross country data on most of these indicators when analyzing a specific sector is not available. Several researchers lined out that patent data, can be preferable as it provides disaggregated information on the innovation in terms of technology, inventor and applications process (Griliches, 1990, Jaffe, 1986). This detailed information allows studying sector specific technology transfer and knowledge spillovers across countries (Dechezlepretre et al., 2011).

Consequently, this study adopts the approach by Dechezlepretre $(\underline{2009} \underline{2011})$ to account for innovation and technology transfer in solar photovoltaic (PV) and wind energy using the classifications scheme developed by Johnstone (2010) and provided by the WIPO IPC Green Inventory (2012) (Table 7).

National innovation is measures as the number of patents invented and filed for in country $i$ (InnoPatApp I $_{t}$ ). The number of innovations transferred from country $i$ to $j$ is measured through patents invented in country i and filed in j ( TransfPat $\left._{i j t}\right)$. To avoid duplications we use fractional counts of DOCDB patent families. In order to obtain the total number of innovations transferred from all $i$ to $j$ in a sector at time $t$ (TotTransfPat ${ }_{\mathrm{j}}$ ) we use the sum of individual country transfers:

$$
\text { TotTransfPat }_{\mathrm{jt}}=\sum_{\mathrm{j}=1}^{\mathrm{i}} \text { TransfPat }_{\mathrm{ijt}} \quad \mathrm{i} \neq \mathrm{j}
$$

The literature on innovation indicates that the productivity of knowledge strongly depends on the existing knowledge (Porter and Stern, 2000, Bosetti et al., 2008). As the process until an innovation reaches the market might take several years it assumed that not only innovation today but also the stock of existing knowledge is relevant to determine its effect on production and export. In order to account for this lag we also use the perpetual inventory method to annual patent applications in wind energy and solar photovoltaic technology. Consequently, the stock of innovation and the stock of innovation, bilateral foreign knowledge stock and total foreign knowledge stock variables are calculated as follows:

$$
\begin{aligned}
\text { IInno }_{\mathrm{it}} & =(1-\delta) \text { Inno }_{\mathrm{it}-1}+\text { InnoPatApp }_{i t} \\
\operatorname{KTrans}_{\mathrm{ij} \mathrm{t}} & =(1-\delta) \operatorname{KTrans}_{\mathrm{ij} \mathrm{t}-1}+\operatorname{TransfPat}_{i j t}
\end{aligned}
$$




$$
\operatorname{KSumTrans}_{\mathrm{j \textrm {t }}}=\sum_{j=1}^{i} \operatorname{KTrans} f_{\mathrm{ij} \mathrm{t}}
$$

and: $i \neq j ; \delta=0.15(0.10)^{11}$

Hence, the stock of innovation (KInno) and transfer (KTransf) equals the respective stock at time $\mathrm{t}-1$ minus its depreciation $(\delta)$ plus patent applications by residents of $\mathrm{i}$ in $\mathrm{i}$ or plus applications of residents of country $i$ in filed in country $j$, respectively.

Table 7: Description for solar PV and wind energy technology relevant IPCs

\begin{tabular}{|c|c|}
\hline IPC & Description \\
\hline \multicolumn{2}{|l|}{ Solar Photovoltaics (PV) } \\
\hline $\begin{array}{l}\text { H01L 27/142, 31/00-31/078 } \\
\text { H01G 9/20 } \\
\text { H02N 6/00 }\end{array}$ & $\begin{array}{l}\text { Devices adapted for the conversion of radiation energy into } \\
\text { electrical energy }\end{array}$ \\
\hline H01L 27/30, 51/42-51/48 & Using organic materials as the active part \\
\hline \multicolumn{2}{|c|}{$\begin{array}{l}\text { H01L 25/00, 25/03, 25/16, Assemblies of a plurality of solar cells } \\
\text { 25/18,31/042 }\end{array}$} \\
\hline \multicolumn{2}{|c|}{ C01B 33/02 } \\
\hline C23C $14 / 14,16 / 24$ & Silicon; single-crystal growth \\
\hline \multicolumn{2}{|l|}{ С30B 29/06 } \\
\hline G05F 1/67 & Regulating to the maximum power available from solar cells \\
\hline F21L 4/00 & \multirow[t]{2}{*}{ Electric lighting devices with, or rechargeable with, solar cells } \\
\hline F21S 9/03 & \\
\hline$\frac{\mathrm{H} 02 \mathrm{~J} 7 / 35}{\mathrm{H} 01 \mathrm{C} / 20}$ & Charging batteries \\
\hline $\begin{array}{l}\text { H01G 9/20 } \\
\text { H01M 14/00 }\end{array}$ & Dye-sensitised solar cells (DSSC) \\
\hline \multicolumn{2}{|l|}{ Wind Energy } \\
\hline F03D & Wind energy \\
\hline H02K 7/18 & $\begin{array}{l}\text { Structural association of electric generator with mechanical driving } \\
\text { motor }\end{array}$ \\
\hline \multicolumn{2}{|l|}{ B63B 35/00 } \\
\hline E04H 12/00 & Structural aspects of wind turbines \\
\hline \multicolumn{2}{|l|}{ F03D 11/04 } \\
\hline B60K 16/00 & Propulsion of vehicles using wind power \\
\hline B60L 8/00 & Electric propulsion of vehicles using wind power \\
\hline B63H 13/00 & Propulsion of marine vessels by wind-powered motors \\
\hline
\end{tabular}

Source: WIPO (2012) - IPC Green Inventory (http://www.wipo.int/classifications/ipc/en/est/)

11 The literature commonly uses a depreciation rate of 15 percent (e.g., Guellec and van Pottelsberghe de la Potterie (2004). We use this depreciation rate and conducted robustness checks with a depreciation rate of 10 percent. An initial knowledge stock is not calculated as, available from PATSTAT available data starts in 1980 which is used as initial year. Considering that solar photovoltaic and wind innovations before that time period were hardly existent, this is a valid approach. Furthermore, using the given rate any stock marginally higher than that given in 1980 is depreciated until 1996 which is the starting year of this analysis. 
Appendix 6: Correlation Matrix for analysis of solar photovoltaic energy component imports

\begin{tabular}{|c|c|c|c|c|c|c|c|c|c|c|c|c|c|c|c|c|}
\hline & 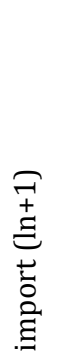 & 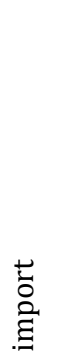 & 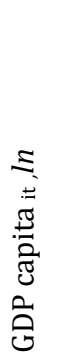 & 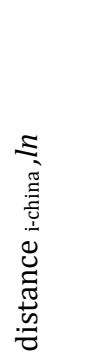 & 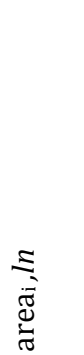 & 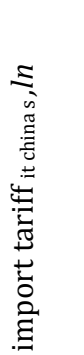 & 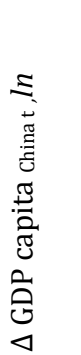 & 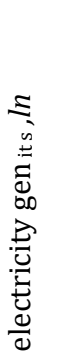 & 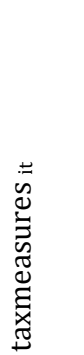 & 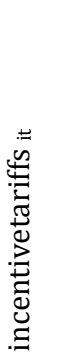 & 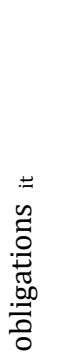 & 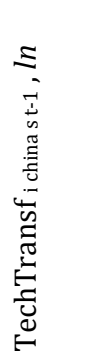 & 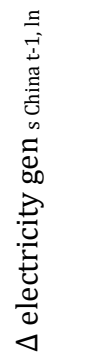 & 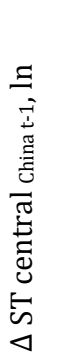 & 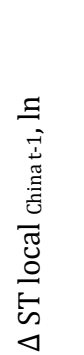 & 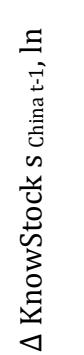 \\
\hline import $(\ln +1)$ & 1 & & & & & & & & & & & & & & & \\
\hline Import & 0.39 & 1 & & & & & & & & & & & & & & \\
\hline GDP per capita it , In & 0.25 & 0.17 & 1 & & & & & & & & & & & & & \\
\hline distance i-china , $\ln$ & -0.09 & -0.12 & 0.07 & 1 & & & & & & & & & & & & \\
\hline $\operatorname{area}_{i}, \ln$ & 0.43 & 0.14 & -0.26 & 0.18 & 1 & & & & & & & & & & & \\
\hline import tariff it chinas, $\ln$ & 0.01 & -0.06 & -0.38 & 0.19 & 0.21 & 1 & & & & & & & & & & \\
\hline$\Delta$ GDPcapita Chinat, $\ln$ & 0.40 & 0.18 & 0.13 & 0.00 & 0.00 & 0.10 & 1 & & & & & & & & & \\
\hline electricity gen ${ }_{\text {it }}, \ln$ & 0.38 & 0.79 & 0.24 & -0.12 & 0.18 & -0.18 & 0.11 & 1 & & & & & & & & \\
\hline taxmeasures it & 0.48 & 0.16 & 0.35 & 0.03 & 0.08 & -0.02 & 0.18 & 0.12 & 10 & & & & & & & \\
\hline incentivetariffs it & 0.40 & 0.15 & 0.46 & 0.12 & -0.12 & -0.14 & 0.24 & 0.12 & 0.52 & 1 & & & & & & \\
\hline obligations it & 0.40 & 0.15 & 0.46 & -0.14 & -0.04 & -0.21 & 0.17 & 0.16 & 0.40 & 0.37 & 1 & & & & & \\
\hline TechTransf $_{\text {i china st }-1}, \ln$ & 0.59 & 0.40 & 0.58 & -0.25 & 0.20 & -0.28 & 0.15 & 0.50 & 0.33 & 0.32 & 0.50 & 1 & & & & \\
\hline $\begin{array}{l}\Delta \text { electricity gen s China } \mathrm{t}-1 \text {, } \\
\ln \text {. }\end{array}$ & 0.24 & 0.14 & 0.07 & 0.00 & 0.00 & -0.07 & 0.24 & 0.08 & 0.09 & 0.14 & 0.10 & 0.08 & 1 & & & \\
\hline$\Delta \mathrm{ST}$ central China $\mathrm{t}-1, \ln$ & 0.15 & 0.07 & 0.04 & 0.00 & 0.00 & 0.07 & 0.42 & 0.04 & 0.05 & 0.08 & 0.04 & 0.05 & 0.32 & 1 & & \\
\hline$\Delta$ ST local China t-1, $\ln$ & -0.04 & 0.10 & -0.01 & 0.00 & 0.00 & 0.04 & -0.10 & 0.03 & -0.07 & -0.06 & -0.07 & -0.02 & -0.34 & 0.17 & 1 & \\
\hline$\Delta$ KnowStock S China $\mathrm{t}-1, \ln$ & 0.40 & 0.19 & 0.12 & 0.00 & 0.00 & -0.01 & 0.71 & 0.12 & 0.18 & 0.22 & 0.19 & 0.14 & 0.53 & 0.45 & -0.18 & 1 \\
\hline
\end{tabular}

Appendix 7: Correlation Matrix for analysis of wind energy component imports

\begin{tabular}{|c|c|c|c|c|c|c|c|c|c|c|c|c|c|c|c|c|}
\hline & 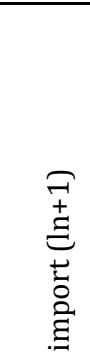 & 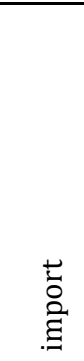 & 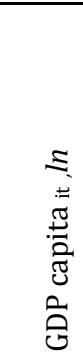 & 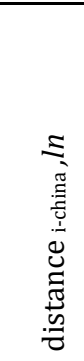 & 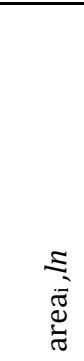 & 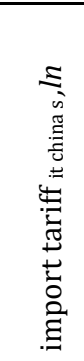 & 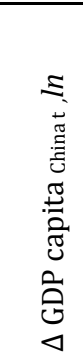 & 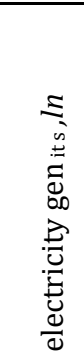 & 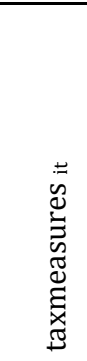 & 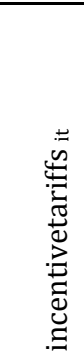 & 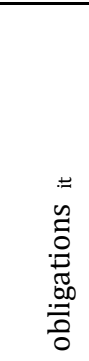 & 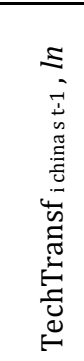 & 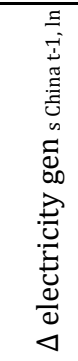 & 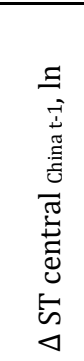 & 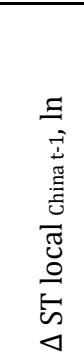 & 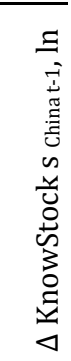 \\
\hline import $(\ln +1)$ & 1.00 & & & & & & & & & & & & & & & \\
\hline Import & 0.36 & 1.00 & & & & & & & & & & & & & & \\
\hline GDP per capita it, In & 0.05 & 0.05 & 1.00 & & & & & & & & & & & & & \\
\hline distance i-china , $\ln$ & -0.14 & -0.10 & 0.07 & 1.00 & & & & & & & & & & & & \\
\hline $\operatorname{area}_{i}, \ln$ & 0.45 & 0.22 & -0.26 & 0.18 & 1.00 & & & & & & & & & & & \\
\hline import tariff it chinas, $\ln$ & 0.13 & 0.05 & -0.45 & 0.08 & 0.24 & 1.00 & & & & & & & & & & \\
\hline$\Delta$ GDPcapita Chinat, $\ln$ & 0.48 & 0.18 & 0.13 & 0.00 & 0.00 & 0.22 & 1.00 & & & & & & & & & \\
\hline electricity gen it s, $\ln$ & 0.48 & 0.46 & 0.27 & 0.04 & 0.20 & -0.07 & 0.24 & 1.00 & & & & & & & & \\
\hline taxmeasures it & 0.30 & 0.08 & 0.35 & 0.03 & 0.08 & -0.16 & 0.18 & 0.38 & 1.00 & & & & & & & \\
\hline incentivetariffs it & 0.19 & 0.07 & 0.46 & 0.12 & -0.12 & -0.29 & 0.24 & 0.39 & 0.52 & 1.00 & & & & & & \\
\hline obligations it & 0.27 & 0.03 & 0.46 & -0.14 & -0.04 & -0.23 & 0.17 & 0.32 & 0.40 & 0.37 & 1.00 & & & & & \\
\hline TechTransf $\mathrm{i}_{\text {c china st }-1}, \ln$ & 0.42 & 0.28 & 0.61 & -0.18 & 0.19 & -0.23 & 0.18 & 0.53 & 0.32 & 0.35 & 0.55 & 1.00 & & & & \\
\hline$\Delta$ electricity gen ${ }_{\mathrm{s}}$ China $\mathrm{t}-1, \mathrm{ln}$ & 0.39 & 0.24 & 0.11 & 0.00 & 0.00 & 0.10 & 0.74 & 0.23 & 0.11 & 0.17 & 0.10 & 0.17 & 1.00 & & & \\
\hline$\Delta \mathrm{ST}$ central China $\mathrm{t}-1, \ln$ & 0.19 & 0.07 & 0.04 & 0.00 & 0.00 & 0.08 & 0.42 & 0.09 & 0.05 & 0.08 & 0.04 & 0.06 & 0.35 & 1.00 & & \\
\hline$\Delta$ ST local China $\mathrm{t}-1, \ln$ & -0.06 & 0.08 & -0.01 & 0.00 & 0.00 & -0.07 & -0.10 & 0.01 & -0.07 & -0.06 & -0.07 & 0.00 & 0.42 & 0.17 & 1.00 & \\
\hline$\Delta$ KnowStock $\mathrm{S}$ China $\mathrm{t}-1, \mathrm{ln}$ & 0.50 & 0.24 & 0.13 & 0.00 & 0.00 & 0.12 & 0.83 & 0.27 & 0.15 & 0.23 & 0.16 & 0.19 & 0.82 & 0.27 & 0.06 & 1.00 \\
\hline
\end{tabular}




\section{Acknowledgements}

The authors would like to thank Jörg Breitung (University Bonn), Meixin Guo (Tsinghua University), Florian Mölders (DIW Berlin) as well as the participants of the $12^{\text {th }}$ IAEE European Energy Conference in Venice, Italy for their valuable comments that substantially improved this article. Financial support by the Heinrich-Böll-Foundation and the DIW Graduate Center of Economic Research is gratefully acknowledged. Jing Cao is supported in part by the National Natural Science Foundation of China under Grants 70803026 and 71173130 and by Tsinghua University Initiative Scientific Research Program. Any remaining errors, omissions, or inconsistencies are the authors' alone. 


\section{References}

ALAVI, R. 2007. An Overview of Key Markets, Tariff s and Non-tariff Measures on Asian Exports of Select Environmental Goods. ICTSD Trade and Environment Series Issue Paper No. 4. Geneva: ICTSD Programme on Trade and Environment.

ALGIERI, B., AQUINO, A. \& SUCCURRO, M. 2011, Going “green”: trade specialisation dynamics in the solar photovoltaic sector, Energy Policy 39(11): 7275-7283.

AMITI, M. \& FREUND, C. 2010. The Anatomy of China's Export Growth. In: FEENSTRA, R. C. \& WEI, S.-J. (eds.) China's Growing Role in World Trade.

ANDERSON, J., E. \& VAN WINCOOP, E. 2003, Gravity with Gravitas: A Solution to the Border Puzzle, American Economic Review 93170-192.

ANDERSON, J. E. 1979, A Theoretical Foundation for the Gravity Equation, American Economic Review 69(1): 106-116.

AWOKUSE, T. O. \& YIN, H. 2010, Does Stronger Intellectual Property Rights Protection Induce More Bilateral Trade? Evidence from China's Imports, World Development 38(8): 1094-1104.

BALASSA, B. 1969, Country Size and Trade Patterns: Comment, The American Economic Review 59(1): 201204.

BALDWIN, R. E. \& TAGLIONI, D. 2006, Gravity for dummies and dummies for gravity equations, CER Discussion Paper No.5850.

BANK, W. 2011. World Development Indicators 2011. Washington D.C.: World Bank.

BELL, M. \& PAVITT, K. 1993, Technological Accumulation and Industrial Growth: Contrasts Between Developed and Developing Countries, Industrial and Corporate Change 2(2): 157-209.

BERGSTRAND, J. H. 1985, The Gravity Equation in International Trade: Some Microeconomic Foundations and Empirical Evidence, Review of Economics and Statistics 67 3474-81.

BERGSTRAND, J. H. 1989, The Generalized Gravity Equation, Monopolistic Competition, and the FactorProportions Theory in International Trade, The Review of Economics and Statistics 71(1): 143-153.

BOSETTI, V., CARRARO, C., MASSETTI, E. \& TAVONI, M. 2008, International energy R\&D spillovers and the economics of greenhouse gas atmospheric stabilization, Energy Economics 30(6): 2912-2929.

BRANSTETTER, L., FISMAN, R. \& FOLEY, C. F. 2005, Do stronger intellectual property rights increase technology transfer? Empirical evidence from U.S. firmlevel panel data, Quarterly Journal of Economics 121321-349.

BTMCONSULT 2011. International Wind Energy Development - Supply Change Assessment 2012. In: NAVIGANT (ed.). Kopenhagen.

BUXTON, T., MAYES, D. \& MURFIN, A. 1991, UK trade performance and R\&D, Econ. Innovation New Technol 1243-256.

CAMERON, A. C. \& TRIVEDI, P. K. 2005. Microeconometrics: Methods and Applications, Cambridge University Press, New York.

CAPROTTI, F. 2009, Chinas Cleantech Landsscape: The Renewable Energy Technology Paradox, Sustainable Development Law \& Policy IX(3): 6-10.

CHAMBERLAIN, G. A. 1980, Analysis of Covariance with Qualitative Data, Review of Economic Studies 47225238.

CHERNI, J. A. \& KENTISH, J. 2007, Renewable energy policy and electricity market reforms in China, Energy Policy 35(7): 3616-3629.

CONSTANTINI, V. \& MAZZANTI, M. 2012, On the green and innovative side of trade competetivness? The impact of environmental policies and innovation on EU exports, Research Policy 41(132-153).

COSTANTINI, V. \& CRESPI, F. 2008, Environmental Regulation and the Export Dynamics of Energy Technologies, Ecological Economics 66447-460. 
DE LA TOUR, A., GLACHANT, M. \& MÉNIÈRE, Y. 2011, Innovation and international technology transfer: The case of the Chinese photovoltaic industry, Energy Policy 39(2): 761-770.

DECHEZLEPRETRE, A. 2009, Does foreign regulation influence domestic investors? The case of renewable energy innovation.

DECHEZLEPRETRE, A., GLACHANT, M., HASCIC, I., JOHNSTONE, N. \& MENIERE, Y. 2011, Invention and Transfer of Climate Change-Mitigation Technologies: A Global Analysis, Review of Environmental Economics and Policy 5(1): 109-130.

DECHEZLEPRÊTRE, A., GLACHANT, M. \& MÉNIÈRE, Y. 2010. What Drives the International Transfer of Climate Change Mitigation Technologies? Empirical Evidence from Patent Data. Fondazione Eni Enrico Mattei Working Papers [Online].

DINDA, S. 2004, Environmental Kuznets Curve Hypothesis: A Survey, Ecological Economics 49431-455.

EATON, J. \& KORTUM, S. 2002, Technology, geography, and trade, Econometrica 70(5): 1741-1779.

EDMONDS, C., LA CROIX, S. \& LI, Y. 2008, China trade: Busting gravity's bounds, Journal of Asian Economics 19(455-466).

EIA 2012. International Energy Statistics. Wahsington D.C.: U.S. Energy Information Administration.

EPI 2011. Annual Solar Photovoltaics Production by Country, 1995-2010 Washington D.C.: Earth Policy Institute.

EPO 2010. World Patent Statistical Database (PATSTAT). In: OFFICE, E. P. (ed.). Munich.

FEENSTRA, R. C., MARKUSEN, J. R. \& ROSE, A. K. 2001, Using the Gravity Equation to Differentiate among Alternative Theories of Trade, Canadian Journal of Economics 34 2430-47.

FLIESS, B. \& KIM, J. A. 2008, Non-Tariff Barriers Faceing Trade in Selected Environmental Goods and Associated Services, Journal of World Trade 42(3)535-562.

FRANKEL, J. A. 1997. Regional Trading Blocs in the World Economic System, Institute for International Economics, Washington D.C.

FU, X. \& GONG, Y. 2011, Indigenous and Foreign Innovation Efforts and Drivers of Technological Upgrading: Evidence from China, World Development 39(7): 1213-1225.

GRAU, T., HUO, M. \& NEUHOFF, K. 2012, Survey of Photovoltaik Industry Policy in Germany and China, Energy Policy 51(20-37).

GREEN, W. H. 2002. Econometric Analysis, New Jersey.

GREENHALGH, C. 1990, Innovaton and Trade Performance in the UK, The Economic Journal 100(400): 105 118.

GRILICHES, Z. 1990, Patents as Economic Indicators: A Survey, Journal of Economic Literature 28(4): 16611707.

GROBA, F. 2011, Determinants of Trade with Solar Energy Technology Components: Evidence on the Porter Hypothesis?, DIW Berlin Discussion Paper No. 1163

GROSSMAN, G. M. \& HELPMAN, E. 1991, Trade, knowledge spillovers, and growth, European Economic Review 35517-526.

GUAN, J. \& MA, N. 2003, Innovative capability and export performance of Chinese firms, Technovation 23(9): 737-747.

GUAN, J. C., YAM, R. C. M., TANG, E. P. Y. \& LAU, A. K. W. 2009, Innovation strategy and performance during economic transition, Research Policy 38(802-812).

GUELLEC, D. \& VAN POTTELSBERGHE DE LA POTTERIE, B. 2004, From R\&D to productivity growth: Do the institutional settings and the source of funds of R\&D matter?, Oxford Bulletin of Economics and Statistics 66(3): 353-378.

GUIMARAES, P. 2008, The fixed effects negative binominal model revisited, Economics Letters 99(1): 63-66. 
HAMWEY, R. M. Year. Environmental Goods: Where Do the Dynamic Trade Opportunities for Developing Countries Lie? In: Hong Kong Trade and Development Symposium at the Sixth WTO Ministerial Conference, 2005. Center for Economic and Ecological Studies.

HASAN, R. \& RATURI, M. 2001, Does investing in technology affect exports? evidence from Indian firms, EastWest Center Working Paper 21.

HIRSCH, S. \& BIJAOUI, I. 1985, R\&D intensity and export performance: a micro view, Weltwirtschaftliches Archiv 121(138-251).

HSIAO, C. 2003. Analysis of Panel Data, Cambridge University Press, Cambridge, United Kingdom.

HU, A. G. 2010, Propensity to Pantent, Competition and Chinas Foreign Patenting Surge, Research Policy 39(7): 985 - 993.

HU, A. G. \& JEFFERSON, G. H. 2009, A great wall of patents: what is behind China's recent patent explosion?, Journal of Developmental Economics 90(1): 57-68.

HU, J. H., TSEN, K. H. \& HUI, S. S. 2010, China Rationalizes its Renewable Energy Policy, The Electricity Journal 23(3).

HU, M.-C. \& MATHEWS, J. A. 2008, China's national innovative capacity, Research Policy 37(9): 1465-1479.

IEA 2004. Renewable Energy, Market \& Policy Trends in IEA Countries, Paris.

IEA 2010. World Energy Outlook 2010, International Energy Agency, Paris.

IEA/IRENA 2012. Global Renewable Energy Policies and Measures Database. Paris.

JAFFE, A. B. 1986, Technological Opportunity and Spillovers of R\&D: Evidence from Firms Patents, Profits, and Market Value, The American Economic Review 76(5): 984 - 1001.

JOHNSTONE, N., HASCIC, I. \& POPP, D. 2010, Renewable energy policies and technological innovation: Evidence based on patent counts, Environmental and Resource Economics 45133-155.

JUG, J. \& MIRZA, D. 2005, Environmental Regulation in Gravity Equations: Evidence from Europe, World Economics 28(11): 1591 - 1615.

KEESING, D. B. 1967, The Impact of Research and Development on United States Trade Journal of Political Economy 75(1): 38-48.

KRUGMAN, P. R. 1979, Increasing returns, monopolistic competition, and international trade, Journal of International Economics 9(469-479).

LEVINSON, A. 2009, Technology, International Trade, and Pollution from US Manufacturing, American Economic Review 992177-2192.

LEWIS, J. I. 2005, From technology transfer to local manufacturing: China`s emergence in the global wind power industry, Doctoral Dissertation o fU.C.Berkeley.

LEWIS, J. I. 2011, Building a national wind turbine industry: experiences from China, India and South Korea, International Journal of Technology and Globalisation 5(3/4): 281-305.

MA, H., OXLEY, L., GIBSON, J. \& LI, W. 2010, A survey of China's renewable energy economy, Renewable and Sustainable Energy Reviews 14438-445.

MADDEN, G. G., SAVAGE, S. J. \& THONG, S. Y. 1999, Technology, investment and trade: empirical evidence for five Asia-Pacific countries, Applied Economics Letters 6(361-363).

MAGNIER, A. \& TOUJAS-BERNATE, J. 1994, Technology and Trade: Empirical Evidence for Major Five Industrialised Countries, Weltwirtschaftliches Archiv 130(3): 494 - 520.

MASKUS, K. E. \& PENUBARTI, M. 1995, How trade-related are intellectual property rights?, Journal of International Economics 39227-248.

MOST 2011. China Science and Technology Statistics Data Book. In: CHINA, M. O. S. A. T. O. T. P. S. R. O. (ed.). Beijing.

MOTOHASHI, K. \& YUAN, Y. 2010, Productivity impact of technology spillovers from multinationals to local firms: Comparing China's automobiles and electronics industries, Research Policy 39(790-798). 
MUNDLAK, Y. 1978, On the Pooling of Time Series and Cross Section Data, Econometrica 46(1): 69-85.

OECD \& EUROSTAT 1999. The Environmental Goods and Service Industry - Manual for Data Collection and Analysis, Paris.

PAMUKCU, T. 2003, Trade Liberalization and Innovation Decisions of Firms: Lessons from Post-1980 Turkey, World Development 31(8): 1443-1458.

PAPACONSTANTINOU, G. 1997, Technology and industrial performance, The OECD Observer 2046-10.

PARK, W. G. \& LIPPOLDT, D. C. 2005. International Licensing and the Strenghtening of Intellectual Property Rights in Developing Countries During the 1990s. OECD Economic Studies [Online], No. 40.

PARK, W. G. \& LIPPOLDT, D. C. 2008. Technology Transfer and the Economic Implications of the Strengthening of Intellectural Property Rights in Developing Countries. OECD Trade Policy Working Papers [Online], No. 62.

PEIDONG, Z., YANLI, Y., JIN, S., YONGHONG, Z., LISHENG, W. \& XINRONG, L. 2009, Opportunities and challenges for renewable energy policy in China, Renewable and Sustainable Energy Reviews 13(2): 439-449.

POPP, D., HASCIC, I. \& MEDHI, N. 2011, Technology and the diffusion of renewable energy, Energy Economomics 33648-662.

PORTER, M. E. \& STERN, S. 2000, Measuring the "ideas" production function: Evidence from international patent output, NBER Working Paper 7891.

POSNER, M. 1961, International trade and technical change, Oxford Economic Papers XIII323-341.

RAFIQUZZAMAN, M. 2002, The impact of patent rights on international trade: Evidence from Canada, Canadian Journal of Economics 35307-330.

REN21 2009. Background Paper: Chinese Renewable Status Report. Paris.

REN21 2011. Renewables 2011: Global Status Report. Paris: REN21 Secretariat.

RODRIK, D. 2006, What's so special about China's exports, NBER Working Papers No. 11947.

ROPER, S. \& LOVE, J. H. 2002, Innovation and export performance: evidence from the UK and German manufacturing plants, Research Policy 311087-1102.

RU, P., QIANG ZHI, FANG ZHANG, XIAOTIAN ZHONG, JIANQIANG LI \& JUN SU 2012, Behind the development of technology: The transition of innovation modes in China's wind turbine manufacturing industry, Energy Policy 4358-69.

SANTOS SILVA, J. M. C. \& TENREYO, S. 2006, The Log of Gravity, The Review of Economics and Statistics 88641-658.

SAWHNEY, A. \& KAHN, M. H. 2012, Understanding cross-national trends in high-tech renewable power equipment exports to the United States, Energy Policy 46308-318.

SCHOTT, P. K. 2008, The relative sophistication of Chinese exports, Economic Policy 535-49.

SMITH, P. J. 1999, Are weak patent rights a barrier to U.S. exports?, Journal of International Economics 48151177.

SMITH, P. J. 2001, How do foreign patent rights affect U.S. exports, affiliate sales and licences, Journal of International Economics 55(2001).

SOETE, L. 1987, The impact of technological innovation on international trade patterns: the evidence reconsidered, Research Policy 16(2-4): 101-130.

STEENBLIK, R. 2005, Liberalisation of Trade in Renewable-Energy Products and and Associated Technologies: Charcoal, Photovoltaic Systems, and Wind Pumps and Turbines, OECD Trade and Environment Working Paper 2005-07.

STEENBLIK, R. 2006, Liberalisation of Trade in Renewable Energy and Associated Technologies: Biodiesel, Solar Thermal and Associated Technologies.

SUN, Y. 2003, Deteminants in foreign patents in China, World Patent Information 25(27-37). 
TAN, X. 2010, Clean technology R\&D and innovation in emerging countries-Experience from China, Energy Policy 38(6): 2916-2926.

TINBERGEN, J. 1962. Shaping the World Economy: Suggestions for an International Economic Policy, The Twentieth Century Fund, New York.

VERNON, V. 1966, International investment and international trade in the product cycle, Quarterly Journal of Economics LXXX190-207.

VERSPAGEN, B. \& WAKELIN, K. 1997, Trade and technology from a Schumpeterian perspective, International Review of Applied Economics 11(181-194).

WAKELIN, K. 1998a, Innovation and export behavior at the firm level, Research Policy 26829 - 841.

WAKELIN, K. 1998b, The role of innovation in bilateral OECD trade performance, Applied Economics 30(11351346).

WANG, C., WEI, Y. \& LIU, X. 2010, Determinants of Bilateral Trade Flows in OECD Countries: Evidence from Gravity Panel Data Models, World Economy 33(7): 894-915.

WANG, F., YIN, H. \& LI, S. 2010, China’s renewable energy policy: Commitments and challenges, Energy Policy 38(4): 1872-1878.

WESTERLUND, J. \& WILHELMSSON, F. 2008, Estimating the gravity model without gravity using panel data, Applied Economics, Taylor and Francis Journals 43(6): 641-649.

WESTPHAL, L. E. 2002, Technology strategies for economic development, Economics of Innovation and New Technology 11275-320.

WIGNARAJA, G. 2012, Innovation, learning, and exporting in China: Does R\&D or a technology index matter?, Journal of Asian Economics 23(3): 224-233.

WIND, I. 2008. HS Codes and the Renewable Energy Sector. International Centre for Trade and Sustainable Development.

WINKELMANN, R. 2008. Econometric analysis of count data, Springer, Berlin.

WIPO 2012. International Patent Classification (IPC) Green Inventory. Geneva, Switzerland: World Intellectual Property Organization.

WOOLDRIDGE, J. 2002. Econometric analysis of cross section and panel data, MIT Press, Cambridge, MA.

WU, C.-Y. \& MATHEWS, J. A. 2012, Knowledge flows in the solar photovoltaik industry: Insights from patenting y Taiwan, Korea, and China, Research Policy 41524-540.

XINYU, G., BO, J., BIN, L., KAI, Y., HONGGUANG, Z. \& BOYUAN, F. 2011, Study on Renewable Energy Development and Policy in China, Energy Procedia 51284-1290.

YANG, L. \& MASKUS, K. E. 2009, Intellectual property rights, technology transfer and exports in developing countries, Journal of Development Economics 90(2): 231-236.

YUE, C. \& HUA, P. 2002, Does comparative advantage explains export pattern in China, China Economic Review 13276-296.

ZENG, Z. 2009, The comparison of innovation activities and international trade effect in China and Japan in the era of knowledge economy: Empirical research on patents as an example, Journal of Chinese Economic and Foreign Trade Studies, 2(3): 211-228.

ZHANG, K. H. \& SONG, S. 2000, Promoting Exports - The role of inward FDI in China, China Economic Review 11385-396.

ZHAO, H. \& LI, H. 1997, R\&D and Export: Analysis of Chinese Manufacturing Firms, The Journal of High Technology Management Research 8(1): 89-105. 